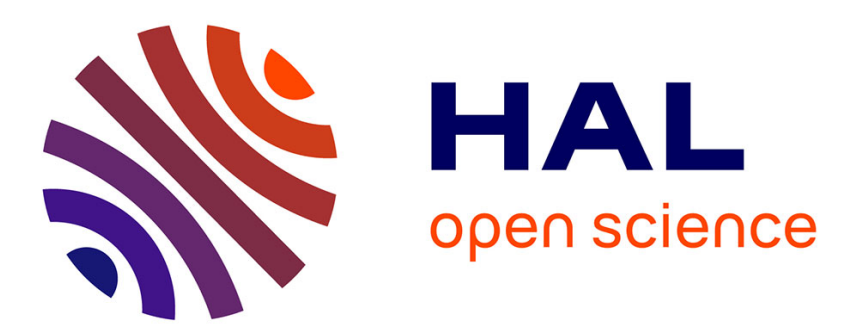

\title{
Mantle flow beneath La Réunion hotspot track from SKS splitting
}

\author{
Guilhem Barruol, Fabrice R. R. Fontaine
}

\section{To cite this version:}

Guilhem Barruol, Fabrice R. R. Fontaine. Mantle flow beneath La Réunion hotspot track from SKS splitting. Earth and Planetary Science Letters, 2013, pp.108-121. 10.1016/j.epsl.2012.11.017 . hal01236138

\section{HAL Id: hal-01236138 \\ https://hal.univ-reunion.fr/hal-01236138}

Submitted on 7 Apr 2016

HAL is a multi-disciplinary open access archive for the deposit and dissemination of scientific research documents, whether they are published or not. The documents may come from teaching and research institutions in France or abroad, or from public or private research centers.
L'archive ouverte pluridisciplinaire HAL, est destinée au dépôt et à la diffusion de documents scientifiques de niveau recherche, publiés ou non, émanant des établissements d'enseignement et de recherche français ou étrangers, des laboratoires publics ou privés. 


\title{
Mantle flow beneath La Réunion hotspot track from SKS splitting
}

\author{
Guilhem Barruol *, Fabrice R. Fontaine \\ Laboratoire GéoSciences Réunion, Université de La Réunion, CNRS, IPGP, UMR 7154, 15 avenue René Cassin, BP 7151, 97715 Saint Denis Cedex 9, La Réunion Island, France
}

\begin{abstract}
A B S T R A C T
If upper mantle anisotropy beneath fast-moving oceanic plates is expected to align the fast azimuths close to the plate motion directions, the upper mantle flow pattern beneath slow-moving oceanic plates will reflect the relative motion between the moving plate and the underlying large-scale convecting mantle. In addition to the non-correlation of the fast azimuths with the plate motion direction, the flow and anisotropy pattern may be locally perturbed by other factors such as the upwelling and the sublithospheric spreading of mantle plumes. Investigating such plume-lithosphere interaction is strongly dependent on the available seismological data, which are generally sparse in oceanic environment. In this study, we take the opportunity of recent temporary deployments of 15 seismic stations and 5 permanent stations on the Piton de la Fournaise volcano, the active locus of La Réunion hotspot and of 6 permanent stations installed along or close to its fossil track of about $3700 \mathrm{~km}$ in length, to analyze azimuthal anisotropy detected by SKS wave splitting and to decipher the various possible origins of anisotropy beneath the Western Indian Ocean. From about 150 good and fair splitting measurements and more than 1000 null splitting measurements, we attempt to distinguish between the influence of a local plume signature and large-scale mantle flow. The large-scale anisotropy pattern obtained at the SW-Indian Ocean island stations is well explained by plate motion relative to the deep mantle circulation. By contrast, stations on La Réunion Island show a complex signature characterized by numerous "nulls" and by fast split shear wave polarizations trending normal to the plate motion direction and obtained within a small backazimuthal window, that cannot be explained by either a single or two anisotropic layers. Despite the sparse spatial coverage which precludes a unique answer, we show that such pattern may be compatible with a simple model of sublithospheric spreading of La Réunion plume characterized by a conduit located at 100-200 km north of La Réunion Island. Anisotropy beneath the new GEOSCOPE station in Rodrigues Island does not appear to be influenced by La Réunion plume-spreading signature but is fully compatible with either a model of large-scale deep mantle convection pattern and/or with a channeled asthenospheric flow beneath the Rodrigues ridge.
\end{abstract}

\section{Introduction}

As plumes move toward the surface, they are expected to interact with the large scale flow induced by mantle convection and with the rigid outermost envelope of the Earth represented by the lithosphere (e.g., Sleep, 1990). This interaction may thermally erode the base of the lithosphere (Li et al., 2004; Thoraval et al., 2006), induce small scale convection (Androvandi et al., 2011) and cause spreading of the plume material beneath the moving plate, generating a parabolic asthenospheric flow pattern (e.g., Ribe and Christensen, 1994; Walker et al., 2005a, 2005b) the signature of which could be revealed by seismic anisotropy.

\footnotetext{
* Corresponding author.

E-mail address: guilhem.barruol@univ-reunion.fr (G. Barruol).
}

Seismic anisotropy provides insights on mantle deformation and therefore on mantle flow and dynamics because it directly results from preferred orientations of the constituting minerals-particularly of the dominant olivine phase-in response to tectonic strain (e.g., Mainprice et al., 2000; Nicolas and Christensen, 1987). In the plate tectonic frame, the sub-oceanic mantle has been an interesting target for a long time, due to the expected well-organized geodynamic processes that may control it, as evidenced by the links between anisotropy and ridge structure seen in seismic refraction profiles in the northern Pacific Ocean (Hess, 1964), or between anisotropy, plate motion, cooling and thickening for the fast-moving plates (Tommasi et al., 1996). At horizontal scale lengths of several hundred of kilometers, seismic anisotropy of the upper mantle is efficiently mapped by surface waves (e.g., Debayle et al., 2005; Montagner, 2002) providing good vertical resolution suggesting that the anisotropy beneath oceans is mostly confined in the uppermost $300 \mathrm{~km}$ of the Earth, i.e., in the lithosphere and the 
asthenosphere. At shorter horizontal scale lengths (i.e., few tenths of kilometers), seismic anisotropy can be robustly measured through the splitting of teleseismic core-shear waves such as SKS phases (e.g., Savage, 1999; Silver and Chan, 1991; Silver, 1996). Although this technique has a poor vertical resolution due to the fact that the delay time between the two split shear waves is integrated along the ray path between the core-mantle boundary and the surface, SKS waves have Fresnel zones radii of about $40-60 \mathrm{~km}$ at depth of 100 and $200 \mathrm{~km}$ and therefore provide good lateral resolution. Interestingly, azimuthal anisotropy, as obtained by horizontally propagating surface waves and by vertically propagating SKS waves, exhibit significant correlation (Becker et al., 2012; Wuestefeld et al., 2009), suggesting that despite their very different vertical and lateral sensitivities, both are affected by the same upper mantle pervasive structures.

In this paper, we used seismic stations installed on La Réunion active volcano, and along or in the vicinity of La Réunion hotspot track (see Fig. 1) to measure the seismic anisotropy and constrain upper mantle deformation and flow. This is a region characterized by a poor instrumental coverage and we discuss the observed pattern of anisotropy in terms of plate motion, deep mantle convection and sublithospheric plume spreading. Anisotropy measurements on volcanic islands generally face the questions of the swell-induced microseismic noise and of upper mantle pervasive structures that may be perturbed by the volcanic activity.

Seismological data recorded at ocean basins and island stations are often dominated by swell-induced microseismic noise (e.g., Barruol et al., 2006). This motivated methodological developments such as extracting better anisotropy signal from noisy environment (e.g., Hammond et al., 2005; Restivo and Helffrich, 1999), stacking of seismological waveforms or of individual shear-wave splitting measurements (Fontaine et al., 2005, 2007; Wolfe and Silver, 1998) or developing independent seismic anisotropy techniques such as the $P$-wave polarization deviation (e.g., Fontaine et al., 2009; Schulte-Pelkum et al., 2001). Fontaine et al. (2007) demonstrated, however, that the much lower amplitude of the swell-induced microseismic noise in the single frequency band (periods between 13 and 20 s) compared with the SKS signal as well as the absence of correlation between the direction of fast split shear wave and the direction of swell-related microseismic noise polarization suggested that the swell has very limited influence on the shear wave splitting measurements.

SKS splitting measurements performed at ocean island stations are often characterized by a large number of "null" measurements (i.e., of unsplit SKS phases) that suggest isotropic structures in the upper mantle. Considering that these islands represent active or frozen volcanic structures, the steeply propagating SKS waves that arrive at about $10^{\circ}$ incidence angles at the station may cross a mantle perturbed by the plume present or past activity beneath the island (Barruol and Hoffmann, 1999). The absence of apparent anisotropy or the difficulty in detecting any anisotropic signal on many islands may therefore reside on that geometrical limitation. This was emphasized for instance in French Polynesia: Ocean bottom seismometers deployed for a one-year experiment on unperturbed ocean floor (Suetsugu et al., 2005; Suetsugu et al., 2009) provided few clear split SKS waveforms (Barruol et al., 2009) whereas anisotropy was undetectable from SKS splitting at Tahiti Island by analyzing two decades of continuous recordings (Fontaine et al., 2007; Russo and

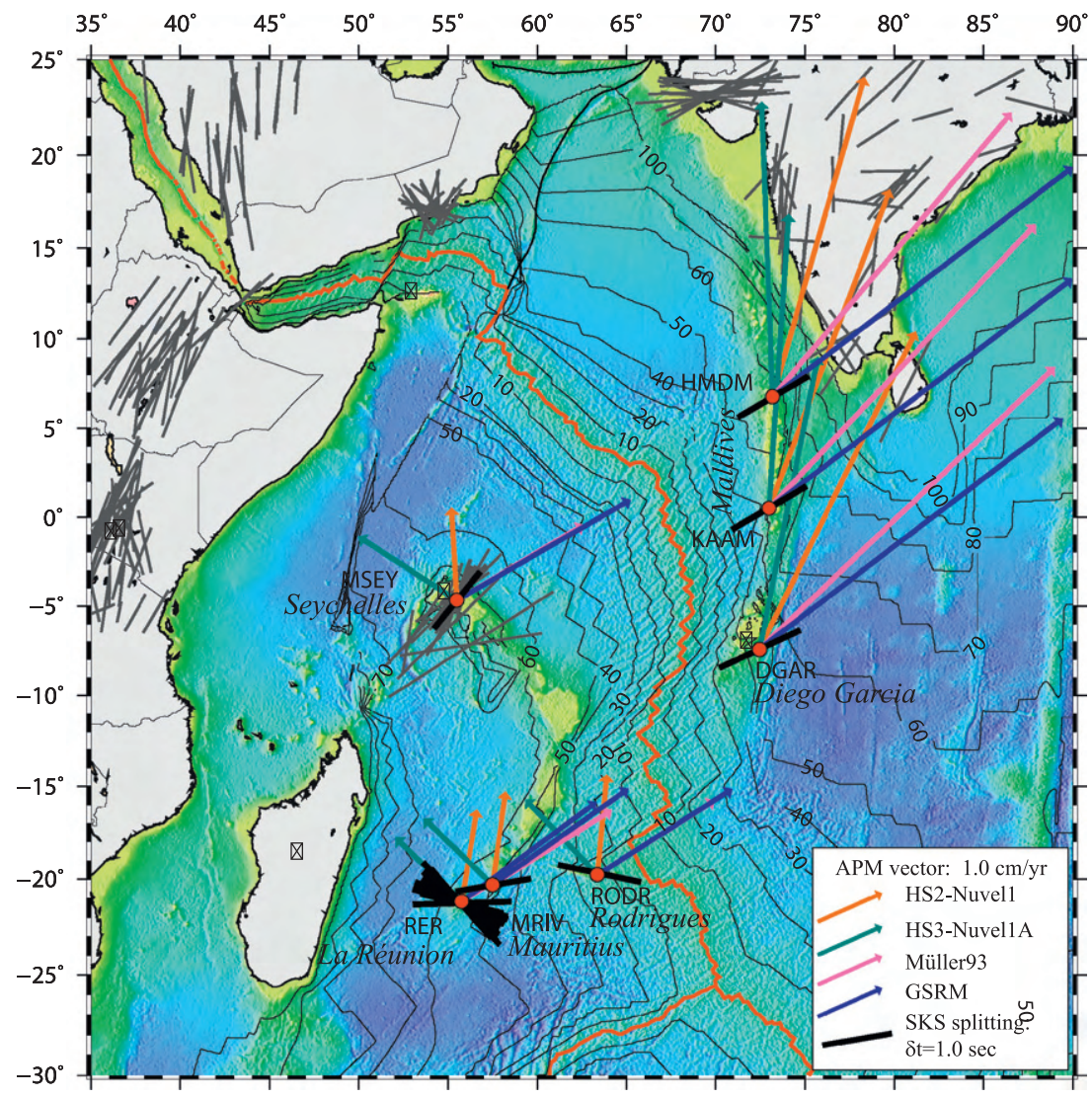

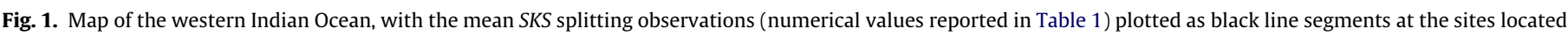

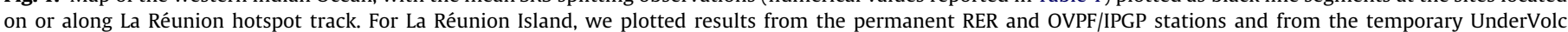

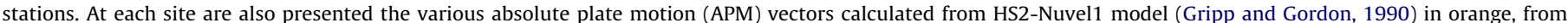

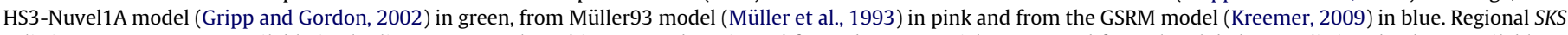

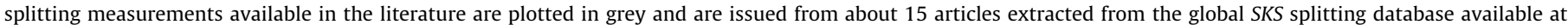
http://www.gm.univ-montp2.fr/splitting/. (For interpretation of the references to color in this figure legend, the reader is referred to the web version of this article.) 
Okal, 1998). On the other hand, anisotropy was detected beneath Tahiti Island by using the $P$-wave polarization analysis (Fontaine et al., 2009), that has the geometrical advantage to use larger incidence angle teleseismic $P$-waves, that sample the upper mantle at larger offset from the expected plume conduit-and likely from the unperturbed upper mantle.

\section{Data and method}

To focus our study on the relationship between La Réunion hotspot and its underlying mantle plume, its fossil track and on the relationship between the moving oceanic plate and the deeper convecting mantle, we choose to restrict our investigation to

Table 1

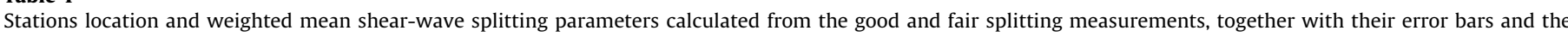

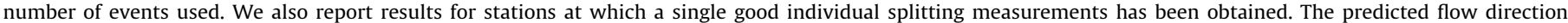
(Conrad and Behn, 2010) and SKS splitting parameters (Becker and Faccenna, 2011) reported in the two last columns are issued from global geodynamic modeling.

\begin{tabular}{|c|c|c|c|c|c|c|c|c|c|c|}
\hline Station & Network & $\begin{array}{l}\text { Latitude } \\
{ }^{\mathrm{N}}\end{array}$ & $\begin{array}{l}\text { Longitude } \\
{ }^{\circ} \mathrm{E}\end{array}$ & $\begin{array}{l}\text { Averaged } \phi \\
\text { (deg.) }\end{array}$ & $\begin{array}{l}\text { Error } \phi \\
\text { (deg.) }\end{array}$ & $\begin{array}{l}\text { Averaged } \delta t \\
(\mathrm{~s})\end{array}$ & $\begin{array}{l}\text { Error } \delta t \\
(\mathrm{~s})\end{array}$ & $\begin{array}{l}\text { Number } \\
\text { of events }\end{array}$ & $\begin{array}{l}\text { Predicted } \phi \\
\text { (Conrad and } \\
\text { Behn, 2010) }\end{array}$ & $\begin{array}{l}\text { Predicted } \phi / \delta \tau \\
\text { (Becker and } \\
\text { Faccenna, 2011) global.2.15 }\end{array}$ \\
\hline HMDM & GEOFON & 6.770 & 73.180 & 59.40 & 15.00 & 1.16 & 0.25 & 6 & - & $73.5 / 2.49$ \\
\hline KAAM & GEOFON & 0.490 & 72.990 & 59.60 & 12.67 & 1.23 & 0.28 & 11 & 35 & $79.5 / 2.58$ \\
\hline DGAR & IRIS & -7.410 & 72.450 & 64.85 & 13.77 & 1.27 & 0.27 & 18 & 49 & $61.2 / 1.92$ \\
\hline MSEY & IRIS & -4.670 & 55.480 & 39.11 & 11.34 & 1.04 & 0.19 & 66 & 60 & $74.4 / 0.56$ \\
\hline MRIV & IRIS & -20.300 & 57.500 & 80.31 & 12.02 & 1.08 & 0.24 & 19 & 87 & $85.2 / 1.69$ \\
\hline RER & Geoscope & -21.170 & 55.740 & 97.30 & 18.84 & 0.77 & 0.35 & 12 & 90 & $83.7 / 1.62$ \\
\hline RODM & Geoscope & -19.696 & 63.441 & 101.89 & 16.67 & 1.20 & 0.35 & 2 & 103 & $84.8 / 1.51$ \\
\hline FJS & OVPF/IPGP & -21.230 & 55.722 & 115.69 & 20.00 & 1.20 & 0.40 & 1 & & \\
\hline FOR & OVPF/IPGP & -21.262 & 55.719 & 139.10 & 18.00 & 1.30 & 0.40 & 2 & & \\
\hline FLR & OVPF/IPGP & -21.241 & 55.733 & - & - & - & - & 0 & & \\
\hline HDL & OVPF/IPGP & -21.251 & 55.791 & 88.36 & 17.00 & 1.40 & 0.40 & 1 & & \\
\hline RVL & OVPF/IPGP & -21.256 & 55.700 & 117.73 & 9.57 & 1.05 & 0.18 & 2 & & \\
\hline SNE & OVPF/IPGP & -21.239 & 55.718 & 122.46 & 17.33 & 1.30 & 0.35 & 2 & & \\
\hline UV01 & UnderVolc & -21.244 & 55.653 & 115.63 & 10.57 & 1.40 & 0.33 & 2 & & \\
\hline UV02 & UnderVolc & -21.274 & 55.779 & - & - & - & - & 0 & & \\
\hline UV03 & UnderVolc & -21.223 & 55.758 & 110.13 & 18.00 & 1.40 & 0.35 & 1 & & \\
\hline UV04 & UnderVolc & -21.267 & 55.762 & 103.34 & 17.00 & 1.20 & 0.30 & 1 & & \\
\hline UV05 & UnderVolc & -21.243 & 55.714 & 118.79 & 15.00 & 1.20 & 0.35 & 1 & & \\
\hline UV06 & UnderVolc & -21.240 & 55.752 & 106.10 & 18.00 & 1.20 & 0.30 & 1 & & \\
\hline UV07 & UnderVolc & -21.229 & 55.692 & 109.75 & 11.00 & 1.40 & 0.15 & 1 & & \\
\hline UV08 & UnderVolc & -21.246 & 55.684 & 106.41 & 10.00 & 1.40 & 0.20 & 1 & & \\
\hline UV09 & UnderVolc & -21.211 & 55.720 & 109.42 & 14.80 & 1.20 & 0.33 & 2 & & \\
\hline UV10 & UnderVolc & -21.284 & 55.725 & 137.24 & 20.00 & 1.60 & 0.40 & 1 & & \\
\hline UV11 & UnderVolc & -21.240 & 55.709 & 115.70 & 15.00 & 1.20 & 0.30 & 1 & & \\
\hline UV12 & UnderVolc & -21.255 & 55.725 & 129.85 & 13.00 & 1.40 & 0.38 & 1 & & \\
\hline UV13 & UnderVolc & -21.292 & 55.708 & 108.69 & 17.00 & 0.80 & 0.25 & 1 & & \\
\hline UV14 & UnderVolc & -21.202 & 55.695 & 108.59 & 15.00 & 1.20 & 0.33 & 2 & & \\
\hline UV15 & UnderVolc & -21.246 & 55.709 & 116.97 & 14.75 & 1.20 & 0.21 & 2 & & \\
\hline
\end{tabular}

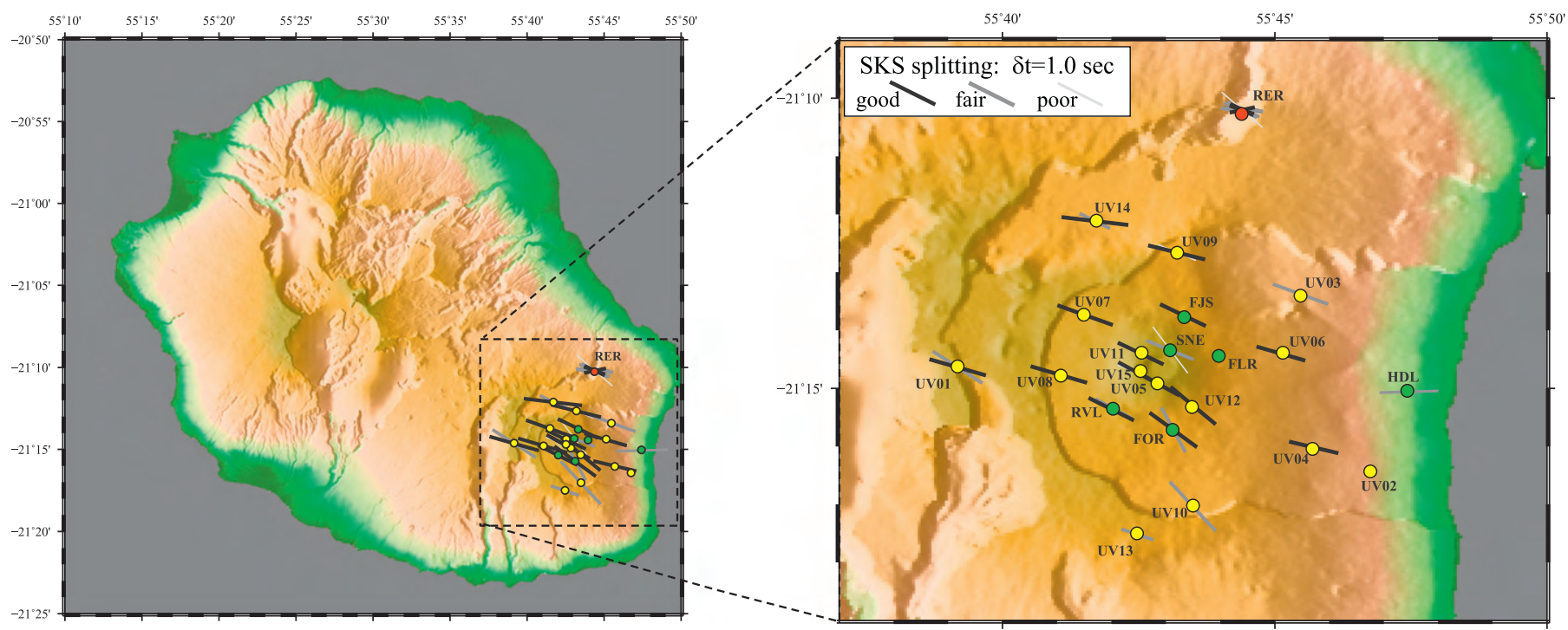

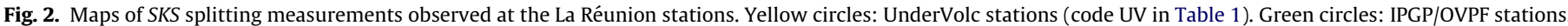

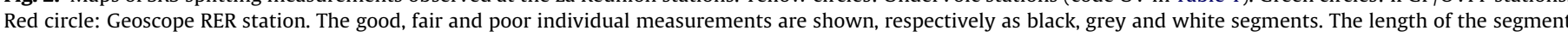

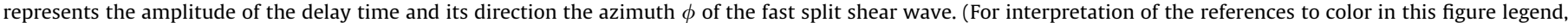
the reader is referred to the web version of this article.) 
seismic stations lying in the western Indian Ocean, on the oceanic plate and on or in the neighborhood of the hotspot track. We did not consider for instance the few permanent stations installed in Madagascar, since the upper mantle anisotropy is likely retracing the long history of the African continental lithosphere, which is out of the scope of this paper. From the 7 permanent stations used in this study (see location in Fig. 1 and Table 1), 3 are installed on the Indian plate in the Maldives area, and the others on the African plate, i.e., with slight differences in plate motion vectors.

On La Réunion Island (Fig. 2), seismic anisotropy beneath the GEOSCOPE station RER was already investigated by several studies providing slightly different interpretations (Barruol and Hoffmann, 1999; Behn et al., 2004). We took the opportunity of this work to reanalyze more than $20 \mathrm{yr}$ of continuous data to better constrain the complex signatures obtained by these studies. We also improved the observations with data acquired by 15 broad band stations deployed during $2 \mathrm{yr}$ on the Piton de la Fournaise active volcano in the frame of the UnderVolc project (station codes UV in Table 1, yellow circles in Fig. 2) which aimed at monitoring the volcanic activity (Brenguier et al., 2012). We also include in our processing 5 permanent broad band stations of the OVPF/IPGP (Observatoire Volcanologique du Piton de la Fournaise/Institut de Physique du Globe de Paris, http://www.ipgp.fr/pages/03030807.php) installed on the volcano (green circles in Fig. 2).

The data availability is strongly station-dependent, from few months of data for the RODM GEOSCOPE station recently installed in Rodrigues Island to more than $20 \mathrm{yr}$ of continuous data available at RER GEOSCOPE station. The GEOFON Maldives stations HMDM and KAAM provided $3 \mathrm{yr}$ of data and IRIS stations DGAR at Diego Garcia and MSEY on Mahé Island in the Seychelles
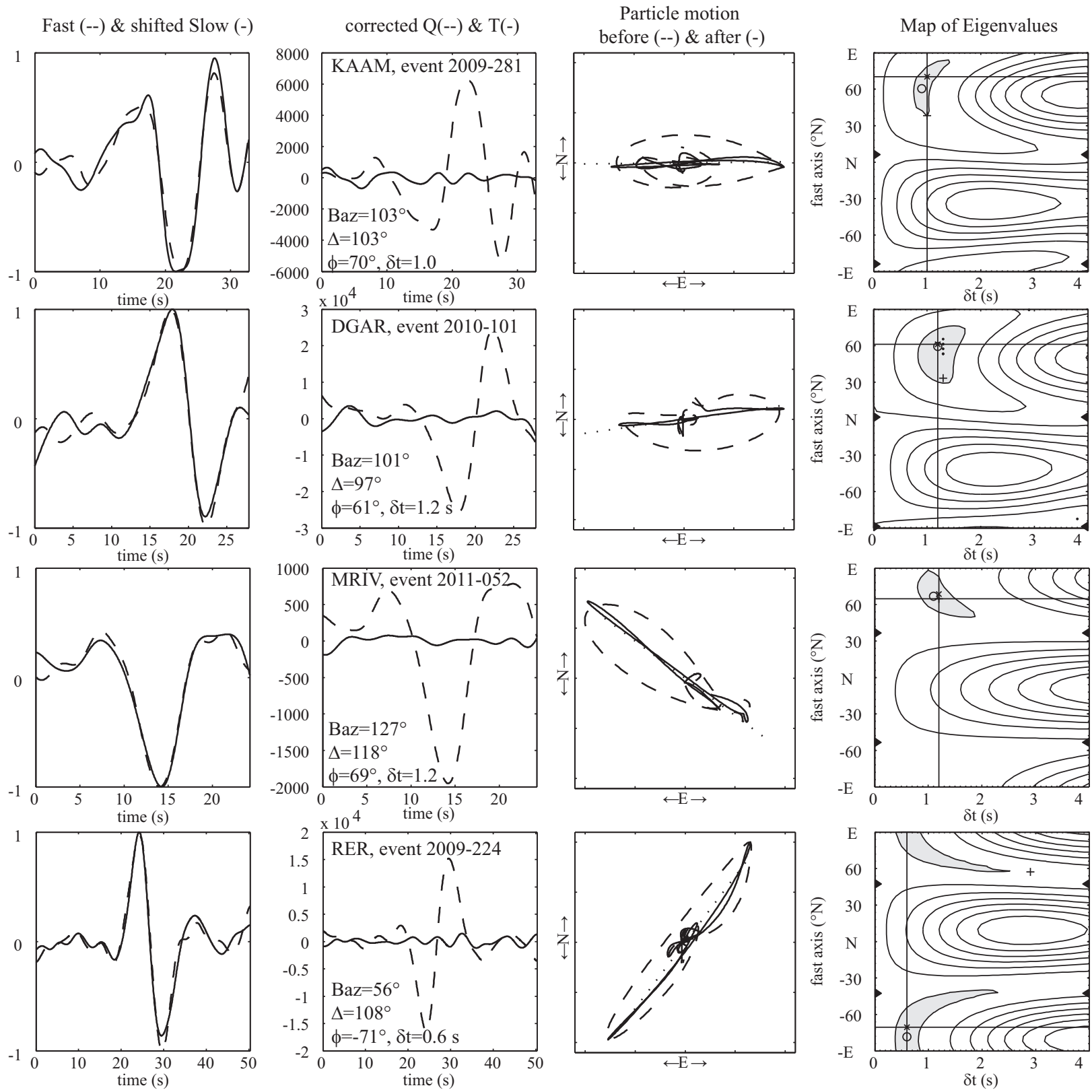

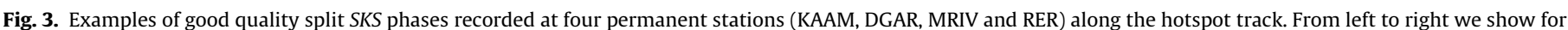

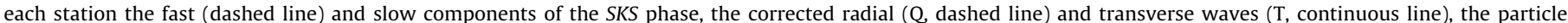

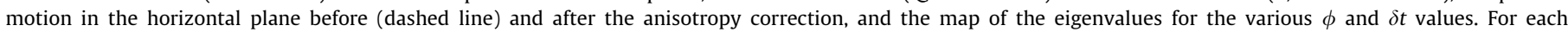

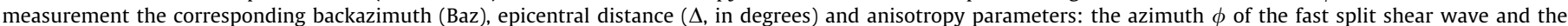
delay time $\delta t$ (in seconds) are indicated. 
provided respectively 7 and $15 \mathrm{yr}$ of data. The Mauritius station MRIV provided 2 yr of data, such as the UnderVolc and the OVPF/ IPGP stations in La Réunion Island.

From the continuous recordings, we extracted and analyzed events with magnitude $\left(M_{b}\right.$ or $\left.M_{w}\right)$ larger than 6.0 occurring at epicentral distance in the range $85-120^{\circ}$, at which SKS phases are the most energetic and with limited interferences with other seismic phases. The shear wave splitting parameters were measured using the SplitLab software (Wuestefeld et al., 2008) and the minimum eigenvalue method (Silver and Chan, 1991) which does not assume a radial polarization direction for the SKS wave before it enters the anisotropic medium. This assumption reduces problems induced by possible sensor misorientation. For each SKS phase, this approach allows us to determine the azimuth of the fast split shear wave $\phi$ and the delay time $\delta t$ between the fast and slow split shear waves. $\phi$ is related to the orientation of the pervasive fabric (foliation and lineation) in the anisotropic structure and $\delta t$ is directly related to the magnitude and thickness of the anisotropic layer.

We determined the quality of each individual measurement by applying manual and automatic approaches. The manual quality factor (Barruol et al., 1997) defined as good, fair, or poor and reported as Manual_Q in Tables S1 and S2 is based on the user evaluation of the signal-to-noise ratio of the initial waveform, of the correlation between the fast and slow shear waves, of the linearity of the particle motion in the horizontal plane after correction and of the size of the 95\% confidence area. The automatic quality factor (Auto_Q) is calculated within SplitLab (Wuestefeld et al., 2008) from the differences between rotationcorrelation and eigenvalue splitting parameters. This factor varies between -1.0 (characterizing a perfect null measurement) and 1.0 (a perfect splitting measurement, providing identical results from the two techniques) and shows good statistical agreement with the manual quality evaluation as shown in a previous study (Barruol et al., 2011).

In order to detect potential frequency dependence of the anisotropy parameters, we systematically filtered the data before the SKS splitting measurements with 10 different band-pass filters centered around 'long' period signal (typically around $30 \mathrm{~s}$ ) to 'short' period signal (typically around $5 \mathrm{~s}$ period) and that removed high frequency ( $>2 \mathrm{~Hz}$ ) and long period $(>100 \mathrm{~s}$ ) signals. This approach did not evidence any systematic frequency dependence of the splitting parameters.

\section{Results}

Systematic analyses of high Signal to Noise Ratio (SNR) SKS phases provided a large majority of 'null' measurements, i.e., of unsplit SKS phases characterized by the fact that the phase energy is concentrated on the radial component. The total splitting database presented in this paper provided more than 1000 'nulls' (listed in Table S1), from which more than 600 were of good quality and from which about 500 were obtained at La Réunion seismic stations and 188 at RER, the other being recorded at the OVPF/IPGP stations and at UnderVolc temporary stations. We succeeded however, to measure a total of 160 split SKS waves among which 71 were of good quality (examples presented Fig. 3). Individual measurements of good and fair quality are listed in Table S2. A total of only 17 good quality individual SKS splitting measurements were obtained at La Réunion Island from $20 \mathrm{yr}$ of data at RER and from $2 \mathrm{yr}$ of data at the 20 UnderVolc and OVPF/IPGP stations. All the individual measurements performed at La Réunion stations are plotted at each station in Fig. 2 showing the homogeneous anisotropy pattern. Interestingly, all of these measurements derive from few events occurring within a very small backazimuthal window ranging from $\mathrm{N} 045^{\circ} \mathrm{E}$ to $\mathrm{N} 065^{\circ} \mathrm{E}$. Most resulting $\phi$ trend between $\mathrm{N} 090^{\circ} \mathrm{E}$ and $\mathrm{N} 120^{\circ} \mathrm{E}$ and the $\delta t$ range between 1.0 and $1.4 \mathrm{~s}$. At most of the UnderVolc and OVPF/ IPGP stations, the only good splitting results we obtained derived from a single event (occurring on 21/12/2010 at 17:19 UTC, with $M_{w}=7.4$, backazimuth $=\mathrm{N} 064^{\circ} \mathrm{E}$, epicentral distance $=109^{\circ}$ ) that provided good measurements at most stations, with $\phi$ trending homogeneously N100-N120 E (Table 1 and Fig. 2). Splitting measurements of this event are reported in Fig. S2.

Despite the proximity of Mauritius Island with La Réunion (around $200 \mathrm{~km}$ between the two islands) and the small time period of data used at MRIV ( $2 \mathrm{yr}$ ), we obtained a rather different anisotropic signature, characterized by a much larger number of good quality splitting measurements. The 10 good quality events that provided $\phi$ consistently trending $\mathrm{N} 080^{\circ} \mathrm{E}$ to EW and $\delta t$ around $1.0 \mathrm{~s}$, as reported in Fig. 3 and Fig. S1 are mostly issued from events with ESE backazimuths, whereas those directions systematically provided nulls at RER, suggesting regional upper mantle heterogeneities and a complex pattern dominated by nulls at La Réunion stations likely induced by the local upper mantle structure beneath the island. Interestingly, the event 21/12/2010 that provided clear non-nulls at La Réunion stations provided a null measurement at MRIV (see Fig. S2).

At the recently installed station RODM on Rodrigues Island, we found a single clear split SKS phase with $\phi$ trending $N 102^{\circ} \mathrm{E}$, i.e., parallel to the general trend of the Rodrigues ridge and with a $\delta t$ of $1.2 \mathrm{~s}$ (Fig. S1).

Most of the high quality SKS splitting measurements in the Western Indian Ocean were obtained at MSEY, on the granitic island of Mahé. Here we obtained 31 good quality individual measurements that fully confirmed within few degrees the existing average of SKS splitting parameters characterized by $\phi$ trending $\mathrm{N}^{\circ} 9^{\circ} \mathrm{E}$ and $\delta t$ of $1.0 \mathrm{~s}$ (Barruol and Ben Ismail, 2001; Behn et al., 2004). Hammond et al. (2005) obtained at MSEY and at the other neighboring Seychelles islands similar values for the fast axis direction ca. $\mathrm{N} 030^{\circ} \mathrm{E}$ and a large variation in $\delta t$ between 0.55 and 1.75 .

The three stations located on the Indian plate section of the hotspot track (HMDM, KAAM and DGAR from north to south) provide homogeneous splitting parameters with mean values trending between $\mathrm{N} 060$ and $\mathrm{N} 065^{\circ} \mathrm{E}$ and $\delta t$ between 1.1 and $1.3 \mathrm{~s}$ (Table 1, Fig. 3 and Fig. S1). Individual measurements at each station are shown in Fig. 4, projected at $200 \mathrm{~km}$ depth along the incoming SKS ray paths.

We searched evidence of backazimuthal variation in the splitting parameters that could reveal the presence of two independent lithospheric and asthenospheric layers (Silver and Savage, 1994). At MSEY (Fig. 4), the fast polarization direction $\phi$ does not exhibit strong backazimuthal variations. The fast azimuths are consistent with the observed null directions and suggest a dominating single anisotropic layer. In La Réunion, the backazimuthal coverage is good (Fig. 4) but the observed $\phi$ directions trending $\mathrm{N} 100^{\circ} \mathrm{E}$ are concentrated along $\mathrm{NE}$ incoming backazimuths and do not describe clear backazimuthal variations that could characterize the presence of 2 anisotropic layers. Our measurements are even not compatible with a single homogeneous anisotropic layer since one should expect $\mathrm{N} 100^{\circ} \mathrm{E}$ trending $\phi$ for SW incoming backazimuths, which is clearly not the case: we only obtain nulls along these directions suggesting either the absence of anisotropy along this direction or a fast or slow polarization direction along the SW directions. Therefore, our findings clearly suggest a three dimensional complex anisotropic structure beneath La Réunion. At the remaining stations analyzed in this work, the small number of splitting measurements together with the poor backazimuthal coverage did not allow to go further. 

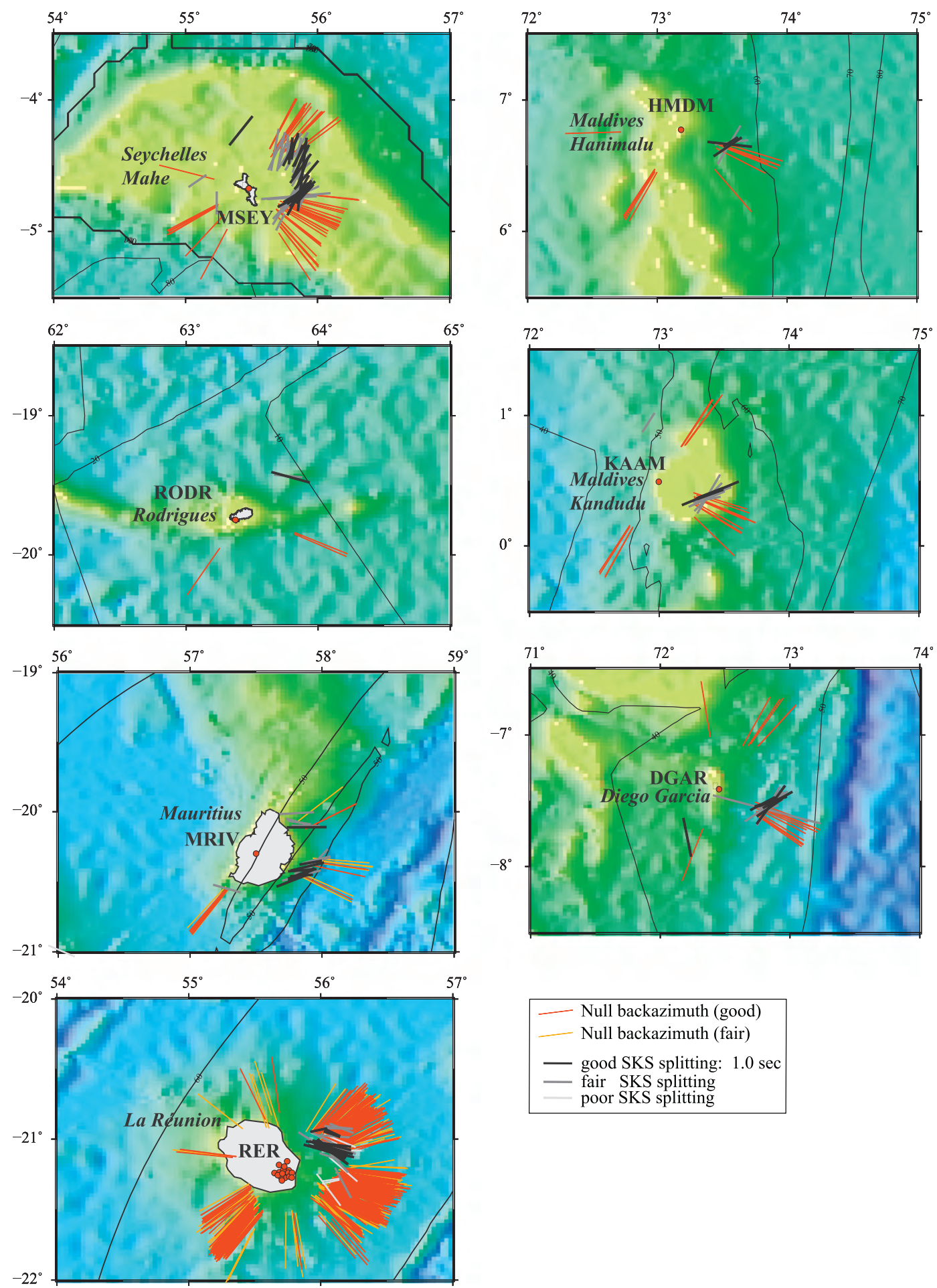

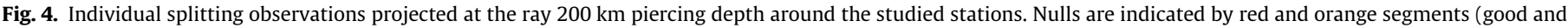

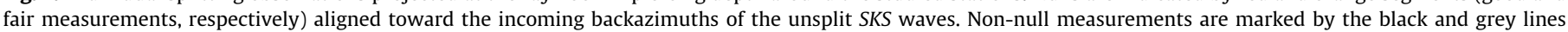

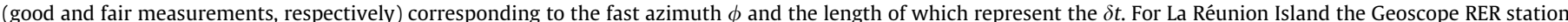

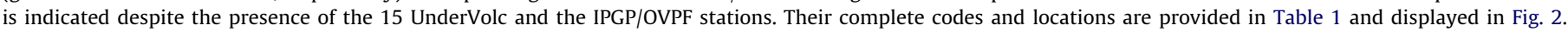
(For interpretation of the references to color in this figure legend, the reader is referred to the web version of this article.)

\section{Discussion}

\subsection{Isotropy or anisotropy beneath La Réunion Island?}

By analyzing about 6 yr of data at RER, Barruol and Hoffmann (1999) concluded in term of isotropy beneath this station since they measured only 2 split SKS phases of only fair quality and 15 nulls of good quality. The backazimuthal coverage of these nulls was clearly not compatible with a simple anisotropic structure beneath the island. By using the stacking procedure developed by Wolfe and Silver (1998), Behn et al. (2004) concluded to an anisotropy oriented $\mathrm{N} 099^{\circ} \mathrm{E}$ with a rather small $\delta t$ of $0.77 \mathrm{~s}$. The present data set increased by 10 more years of data at RER and using $2 \mathrm{yr}$ of data at the 15 UnderVolc stations and at the 
5 OVPF/IPGP stations confirms the presence of split SKS waves of good quality beneath La Réunion Island. The good measurements obtained at RER (Table S2 and Fig. 3), and at the UnderVolc and OVPF/IPGP stations (Figs. S2 and S3) suggest homogeneous consistent anisotropy signature, as shown in Fig. 4 when one projects all individual measurements at $200 \mathrm{~km}$ depth. Interestingly, these observations clearly confirm the previously published results: all good measurements are issued from events that arrive at La Réunion within a small backazimuthal window, ranging from $\mathrm{N} 045^{\circ}$ to $\mathrm{N} 065^{\circ} \mathrm{E}$, as for instance, the event on $21 / 12 / 2010$ reported in Fig. S2. The mean anisotropy we calculated at RER with the 12 fair and good non-null measurements is characterized by a $\phi$ trending $N 097^{\circ} \mathrm{E}$ and by a $\delta t$ of $0.77 \mathrm{~s}$ (Table 1 ), i.e., fully compatible with the values provided by Behn et al. (2004), but as explained above, not compatible with a simple, single-layered anisotropic structure. In case of single and horizontal anisotropic layer, one should indeed observe split SKS waves for SW backazimuths, i.e., at $180^{\circ}$ of the azimuths where clear split phases are observed, which is clearly not the case. The total number of nulls at RER is of 280 from which 188 are of good quality (Table S1). They cover a large range of backazimuths, evidencing a complex structure beneath the island. Our observations are also not compatible with multiple anisotropic layers since we should observe a periodicity in the splitting parameters, which is also not the case. Both the non-null and null anisotropy patterns therefore argue for a laterally heterogeneous upper mantle beneath La Réunion Island.

\subsection{Location of the anisotropy}

Although split SKS waves cannot directly provide the information concerning the depth of anisotropy, surface wave tomography of the Indian Ocean (e.g., Debayle et al., 2005) clearly shows that anisotropy which is present at $50 \mathrm{~km}$ depth, is strongest at $100 \mathrm{~km}$ depth, still present at $150 \mathrm{~km}$, starting to vanish at $200 \mathrm{~km}$, very small at $300 \mathrm{~km}$ and absent at $400 \mathrm{~km}$ depth, meaning that most of the upper mantle deformation is concentrated within the lithosphere and in the underlying asthenosphere.

SKS waves integrate the anisotropy of the various layers or structures crossed by the seismic waves propagating along steeply dipping paths beneath each station. Separating a possible lithospheric from an asthenospheric contribution is not straightforward and requires assumptions on the lithosphere thickness and on its intrinsic amount of anisotropy: the oceanic lithosphere thickness can be estimated beneath each station using the simple cooling and thickening assumption that the oceanic lithosphere thickness $e$ is related to the plate age $t$ through a relation such as $e=9.1 t^{0.5}$, (e.g., Fowler, 1990) with $e$ in $\mathrm{km}, t$ in Ma and for a thermal diffusivity of $0.804 \times 10^{-6} \mathrm{~m}^{2} \mathrm{~s}^{-1}$. Using such relationship, the resulting lithosphere thickness is expected to range between $36 \mathrm{~km}$ at RODM ( $16 \mathrm{Ma}$ old lithosphere) and $74 \mathrm{~km}$ at La Réunion, (67 Ma old lithosphere). This plate-cooling formula cannot be applied to the Seychelles, of continental origin, where the lithosphere thickness beneath MSEY has been estimated to be $100 \mathrm{~km}$ from seismic velocity anomalies (Conrad and LithgowBertelloni, 2006).

The thickness of the anisotropic layer is estimated from the following relationship (Silver and Chan, 1991):

$L=\frac{\delta t}{K s} \times \beta o$

where, $L$ is the thickness of the anisotropic layer, $K s$ is the intrinsic anisotropy and $\beta_{o}$ the isotropic shear velocity. Assuming an averaged intrinsic anisotropy of $4 \%$ as observed in natural peridotites (e.g., Mainprice and Silver, 1993; Mainprice et al., 2000) and $\beta_{o}=4.5 \mathrm{~km} / \mathrm{s}$, the required anisotropic layer thickness $L$ to explain our delay time observations at oceanic stations is characterized by a median value of $135 \mathrm{~km}$. The maximum contribution of the lithosphere on anisotropy is then defined as the ratio between $e$ and $L$ at each station. Our results show that the lithosphere contribution may explain most of the observed delay time at RER ( $86 \%$ of the $\delta t$ may be explained by the lithosphere), where we have a small $\delta t$ value of $0.7 \mathrm{~s}$, but only $\sim 50 \%$ of the observed $\delta t$ over the whole data set, suggesting that about half of the anisotropy detected in this work has to reside at sublithospheric depths.

\subsection{Fast polarization direction and absolute plate motion direction relationships}

Excepting local or regional effects induced by mantle upwelling and sub-lithospheric spreading, seismic anisotropy beneath oceanic basins should primarily result from the frozen lithospheric structure and from the sublithospheric mantle shearing. The first is acquired from gradual lithosphere cooling, thickening and freezing of sublithospheric flow. Several anisotropic layers may be present within the lithosphere in case of plate motion change through time. The second one results from the shearing of the sublithospheric mantle in response to a velocity gradient between the plate (rigid lithosphere) and the deeper mantle. For plates moving at velocities notably larger than the deep convection, this process should align the olivine [100] axes, and therefore the polarization direction of the fast split shear waves close to the absolute plate motion direction. In the South Pacific for instance, the parallelism between $\phi$ and the Pacific absolute plate motion (APM) (Barruol et al., 2009; Fontaine et al., 2007) suggests indeed that the olivine [100] axes at sublithospheric depth are aligned close to the APM direction. In the Indian Ocean, the African and Indian plates move at much smaller velocities, and the plate motion vectors are poorly constrained: models HS2-Nuvel1a (Gripp and Gordon, 1990) and HS3-NUVEL1A (Gripp and Gordon, 2002) are predominantly controlled by the Pacific hotspot tracks and do not take into account the La Réunion hotspot track. The Müller93 model (Müller et al., 1993) accounts for the Indo-Atlantic hotspot tracks but determines the motion of plates relative to hotspots assumed to be fixed in the mantle. As expected for slow-moving plates, we observe little correlation between $\phi$ and the APM vectors (Fig. 1): at La Réunion and Rodrigues islands, $\phi$ trends $\mathrm{N} 080^{\circ} \mathrm{E}$ to $\mathrm{N} 120^{\circ} \mathrm{E}$ and the APM trends $\mathrm{N}^{\circ} 5^{\circ} \mathrm{E}$ at $1.3 \mathrm{~cm} \mathrm{yr}^{-1}$ for HS2-Nuvel1a (Gripp and Gordon, 1990), N044 ${ }^{\circ} \mathrm{W}$ at $1.3 \mathrm{~cm} \mathrm{yr}^{-1}$ for HS3-NUVEL1A (Gripp and Gordon, 2002) and N057 ${ }^{\circ} \mathrm{E}$ at $2.0 \mathrm{~cm} \mathrm{yr}^{-1}$ for Müller93 model

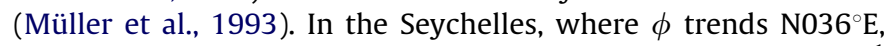
it is closer to Müller93 model trending $\mathrm{N} 059^{\circ} \mathrm{E}$ at $2.1 \mathrm{~cm} \mathrm{yr}^{-1}$ than HS3-NUVEL1A (N057 $\mathrm{W}$ at $1.7 \mathrm{~cm} \mathrm{yr}^{-1}$ ) or HS2-NUVEL1A $\left(\mathrm{N} 003^{\circ} \mathrm{W}\right.$ at $1.3 \mathrm{~cm} \mathrm{yr}^{-1}$ ). On the Indian plate, characterized by faster velocities, the fit of $\phi$ observed at the HMDM, KAAM and DGAR stations (ranging N060-N065 ${ }^{\circ} \mathrm{E}$ ) is rather good with the Müller93 model (trending $\mathrm{N} 039^{\circ} \mathrm{E}$ at $5.3 \mathrm{~cm} \mathrm{yr}^{-1}$ to $\mathrm{N} 046^{\circ} \mathrm{E}$ at $5.8 \mathrm{~cm} \mathrm{yr}^{-1}$ from $\mathrm{N}$ to $\mathrm{S}$ ) but poor with HS2-NUVEL1A (trending $\mathrm{N} 015^{\circ} \mathrm{E}$ at $4.8 \mathrm{~cm} \mathrm{yr}^{-1}$ to $\mathrm{N} 026^{\circ} \mathrm{E}$ at $5.2 \mathrm{~cm} \mathrm{yr}^{-1}$ from $\mathrm{N}$ to $\mathrm{S}$ ) or HS3-NUVEL1A (trending $\mathrm{N} 002^{\circ} \mathrm{W}$ to $\mathrm{N} 011^{\circ} \mathrm{E}$ at $4.2 \mathrm{~cm} \mathrm{yr}^{-1}$ from $\mathrm{N}$ to $\mathrm{S})$.

APM model GSRM-APM-1 (Kreemer, 2009) is different from the models discussed above since it is built from the minimization of oceanic and cratonic SKS fast split direction observations. This model assumes the deformation is induced by the relative motion between the plate and the deeper mantle and concentrated within the asthenosphere. At the African plate stations, GSRM-APM-1 does not fit our observations well, except at MSEY where the difference in azimuth is of $20^{\circ}\left(\phi=\mathrm{N} 039^{\circ} \mathrm{E}\right.$ and $\mathrm{APM}=\mathrm{N} 059^{\circ} \mathrm{E}$ at $\left.2.9 \mathrm{~cm} \mathrm{yr}^{-1}\right)$, suggesting that plate motion alone 
cannot explain our SKS splitting observations and that either fossil lithospheric anisotropy, or convection-related flow or mantle plume related flow may also participate to the upper mantle anisotropy. On the Indian plate (Fig. 1), although GSRM-APM-1 model does not take into account any SKS splitting measurement from the Indian ocean, the predicted plate motion $\left(\mathrm{N} 052^{\circ} \mathrm{E}\right.$ at $5.4 \mathrm{~cm} \mathrm{yr}^{-1}$ ) is very close to our $\phi$ observations at the three stations ( $\phi$ trending $\mathrm{N} 060$ to $\mathrm{N} 065^{\circ} \mathrm{E}$ ), suggesting that plate motion is a viable candidate to explain anisotropy at these stations (HMDM, KAAM and DGAR). Considering their respective positions along the hotspot track, one can assume that the upper mantle beneath these stations has not been affected by the plume flow or other local effects during the last $40 \mathrm{Ma}$ (e.g., Duncan and Hargraves, 1990). The good fit between $\phi$ and GSRM-APM-1 may hence reside in the progressive reorientation of the mantle fabric parallel to the APM and in the erasing or reorientation of the plume-induced mantle flow. It has to be noted that GSRM-APM-1 is close to the absolute plate velocities in the Indo-Atlantic hotspot reference frame (Forte et al., 2010; Quéré et al., 2007).

\subsection{Anisotropy and deep mantle convection}

Several recent studies (e.g., Becker and Faccenna, 2011; Conrad and Behn, 2010; Forte et al., 2010) analyzed and emphasized the role of the deep mantle dynamics on the African and Indian plate motion, and on the sublithospheric mantle flow beneath the western Indian Ocean that may leave a detectable imprint in the anisotropy pattern.

The origin of upper mantle seismic anisotropy beneath the African plate was discussed by Behn et al. (2004) and tested against several hypotheses of plate motion, slab pull and of flow driven by a combination of plate-motion and mantle density heterogeneity. By using the S20RTS global tomographic model (Ritsema et al., 1999), Behn et al. (2004) derived the mantle density heterogeneity and predicted the mantle flow in the asthenosphere, and showed that the combination of active rising flow induced by the low density anomaly beneath southern Africa and the East African Rift, together with the plate motion, provided the best fit to explain the SKS splitting observations. More recently, Conrad et al. (2007) and Conrad and Behn (2010) improved their global viscous mantle flow models by deriving the mantle density heterogeneity from the more recent seismic tomography model S20RTSb (Ritsema et al., 2004), but also by including variations in the lithosphere thicknesses and by testing various plate kinematics. Fitting the azimuthal anisotropy pattern to the tomography-derived mantle flow models allowed them to constrain both the mantle viscosity profile and the possible net rotation of the whole lithosphere. They determined the mantle flow field through the calculation of the infinite strain axis (ISA), i.e., the asymptotic orientation of the long axis of the finite strain ellipsoid in the limit of an infinite strain (Kaminski and Ribe, 2002). Such ISA was demonstrated to be a good proxy for the fast anisotropic direction $\phi$ by Kaminski and Ribe (2002) particularly in regions of large and non-rotating shear avoiding to model complex olivine lattice preferred orientations (LPO). Such assumption was validated by introducing the dimensionless "grain orientation lag" parameter $\Pi$ that quantifies the rotation rate between the local LPO adjustment timescale to the timescale for changes of the ISA (Kaminski and Ribe, 2002). Small $\Pi$ values $(\Pi<0.5)$ suggest that LPO is aligned parallel to the ISA and therefore to the mantle flow direction, whereas large $\Pi$ values $(\Pi>0.5)$ characterize areas where there is no relationship between the LPO and the ISA. Comparing SKS splitting observations with the ISA orientations is therefore restricted to regions of small $\Pi$ values.
Despite the sparse SKS splitting availability in the ocean basins that induces strong non-uniqueness of the model that may explain the observations, Conrad and Behn (2010) found a good fit between the SKS fast polarization directions and the ISA, particularly in the Pacific ocean, but also at the few available stations in the Indian Ocean. Fig. 5a presents a detailed map of their predicted ISA orientation at $200 \mathrm{~km}$ depth beneath the western Indian Ocean, together with our new SKS splitting measurements (in red). We also report Fig. 5a areas where $\Pi$ parameters are larger than 1.0, i.e., where the predicted flow should not be directly compared to SKS splitting measurements. Mid-ocean ridges are clearly associated to large $\Pi$ values. Table 1 summarizes the predicted values of the ISA orientations at $200 \mathrm{~km}$ beneath each of the studied stations. Among the 7 sites analyzed in this paper, only station HMDM in the Maldives is clearly within a large region of $\Pi>1.0$ and we note that at this station, the observed $\phi\left(\mathrm{N} 059^{\circ} \mathrm{E}\right)$ is indeed at large angle to the ISA orientation $\left(\mathrm{N} 177^{\circ} \mathrm{E}\right)$. The three other northern stations show rather good fit between the predicted ISA and $\phi$ orientations (respectively of $\mathrm{N060}$ and $\mathrm{N} 035^{\circ} \mathrm{E}$ at KAAM, N049 and $\mathrm{N065}{ }^{\circ} \mathrm{E}$ at DGAR and N039 and N060 ${ }^{\circ}$ at MSEY), i.e., with differences smaller than $25^{\circ}$. The three stations in the south (RODM, MRIV and RER) are all located close to the $\Pi=1.0$ boundary but still with $\Pi$ values much lower than 1.0, suggesting that a comparison between the predicted flow and the observed SKS splitting is still coherent. The fit between the ISA and $\phi$ orientations at these three sites is particularly good: respectively of N090 and N097 ${ }^{\circ}$ E at RER, N087 and $\mathrm{N} 080^{\circ} \mathrm{E}$ at MRIV and $\mathrm{N} 103$ and $\mathrm{N} 102^{\circ} \mathrm{E}$ at RODM, i.e., with differences systematically smaller than $10^{\circ}$, i.e., within the uncertainty of the individual splitting measurements. The overall good fit between the predicted mantle flow and the observed $\phi$ directions strongly suggests that the anisotropy directions does not rely on the plate motion alone but is instead a combination of plate motions and mantle density heterogeneities related to large-scale mantle upwelling.

Becker and Faccenna (2011) predicted global mantle circulation from density distribution issued from the composite SMEAN $S$-wave tomography model (Becker and Boschi, 2002). Their model evidenced a large convection cell rising from beneath South Africa and plunging below India and Eurasia. They suggest that the active upwelling of the convection cell is an efficient driving force that may drag the Arabian and Indian plates towards the Himalayan collision, respectively along NNW and NNE directions. Such relative motion between the plate and the deeper convection is expected to induce a large sublithospheric horizontal shear and therefore, a large anisotropy from which shear wave splitting parameters can be predicted. By assuming a steady 3D flow, olivine lattice preferred orientation, and the corresponding elastic tensors characterizing the anisotropic properties are calculated along the flow lines at each node of the grid (10 and $50 \mathrm{~km}$ in lateral and vertical spacing, respectively) (Becker et al., 2006). Using a propagator matrix allowing a vertical integration of the seismic properties, synthetic waveforms are then calculated to predict the splitting parameters at the surface.

We compare our SKS splitting observations with the model global.2.15 (Becker, T.W., personal communication, 2012) characterized by radial and lateral viscosity variations inferred from temperature anomalies. From a qualitative point of view, the upper mantle shear for this model is controlled by the differential motion between the African and Indian plate motions and the NE to ENE-trending sublithospheric active flow dominating between 200 and $300 \mathrm{~km}$ depth. The difference in velocity vectors between the plate motion and the asthenospheric flow generates a NE-trending relative shear beneath the Maldives stations on the faster oceanic Indian plate, whereas the relative motion is oriented more EW at the southern stations installed on the slower African plate. From a quantitative point of view, we report in Table 1 

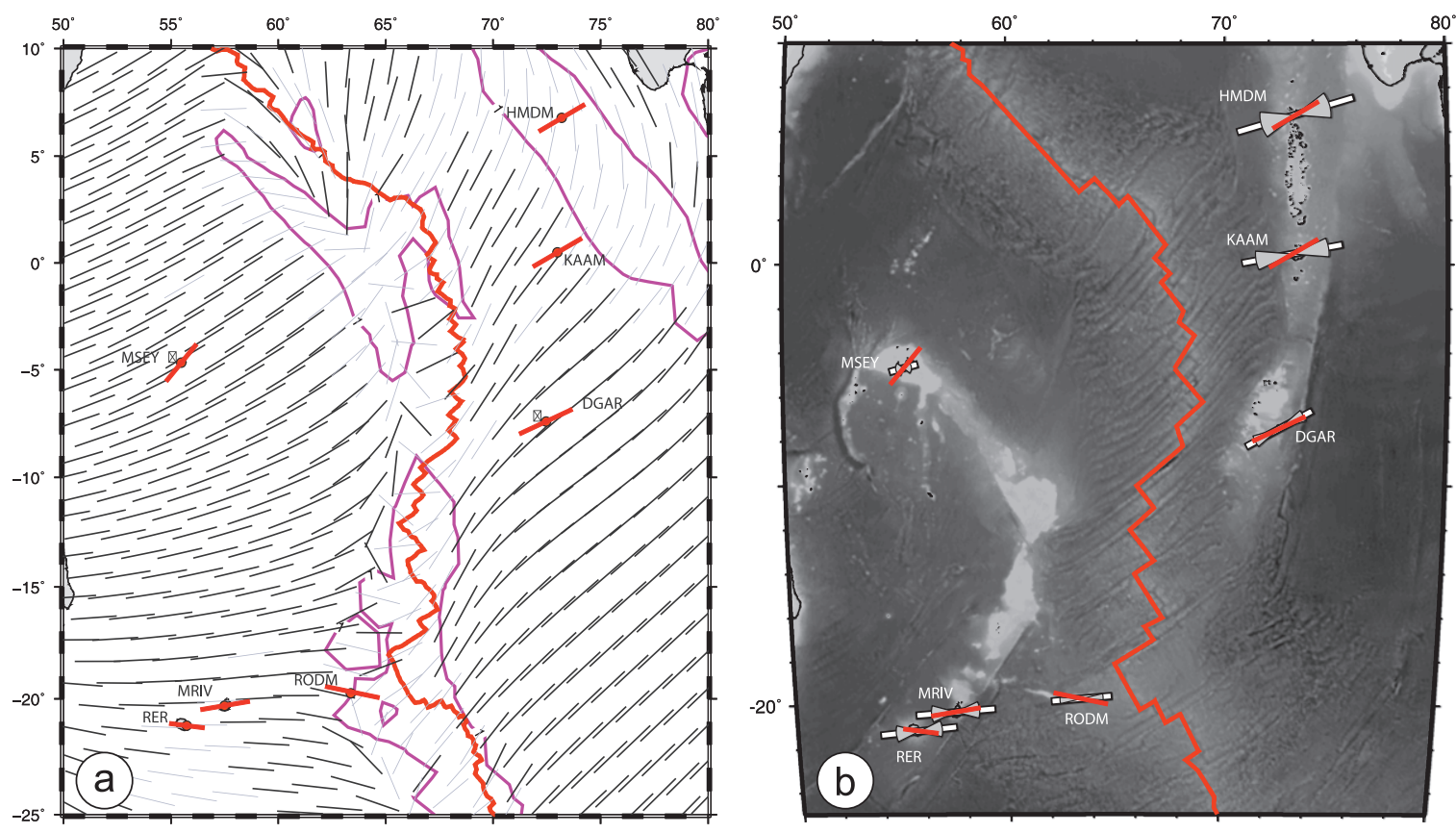

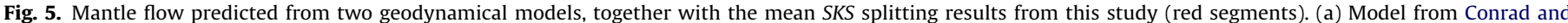

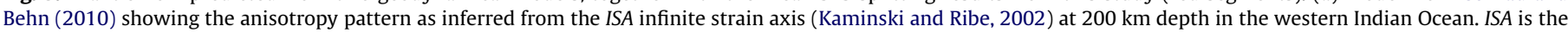

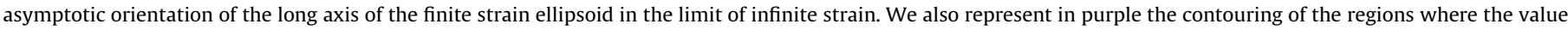

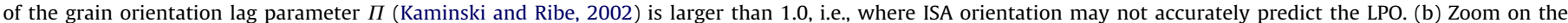

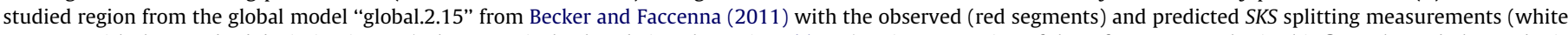

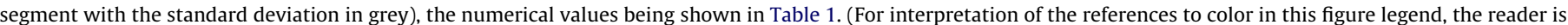
referred to the web version of this article.)

and plot in Fig. 5b the anisotropy parameters $\phi$ and $\delta t$ predicted at each of the studied stations for this geodynamical model (Becker, T.W., personal communication, 2012). At the Diego Garcia and Maldives stations, the predicted $\phi$ trend $\mathrm{N} 061$ to $\mathrm{N} 080^{\circ} \mathrm{E}$ whereas they trend $\mathrm{N} 083^{\circ} \mathrm{E}$ to $\mathrm{N} 085^{\circ} \mathrm{E}$ at the southern stations. In both regions, the fit between the observed $\phi$ and the predictions is within $15-20^{\circ}$, which is fairly good considering on one side the intrinsic splitting measurements errors which are not better than $\pm 10^{\circ}$ for $\phi$ and on the other side all the errors and assumptions taken into account in the geodynamical modeling of mantle flow.

The predicted $\delta t$ reported in Table 1 and shown in Fig. 5b are generally larger than the observed $\delta t$. This can be induced on the modeling side by an overestimation of either the shear strain or the sheared layer thickness or by the fact that olivine may not deform by dislocation creep over the whole upper mantle. On the SKS measurement side, one should expect large delay times, not induced by the plate velocities, which are rather small in these regions, but instead by the long time period of mantle strain integration, since the plate motion directions did not change significantly during the last 20$40 \mathrm{Ma}$. The rather low observed $\delta t$ values may not indicate a weakly deformed asthenosphere but may result from the fact that vertically propagating SKS waves may sample the upper mantle along a weakly anisotropic direction. Microstructural and petrophysical analyses of mantle rocks show indeed that the direction normal to the foliation (i.e., the $Z$ structural direction) is often a weakly anisotropic direction for shear waves (e.g., Ben Ismail and Mainprice, 1998; Mainprice et al., 2000). An illustration of such behavior is provided by the olivine preferred orientations measured in harzburgite nodules sampled within the Kerguelen Island basalts (Bascou et al., 2008). Those fabrics systematically induce strong anisotropy for shear waves propagating parallel to the foliation plane and low anisotropies for shear waves propagating normal to the foliation (Bascou et al., 2008). Beneath the western Indian Ocean, the mantle convection described by geodynamical models induce a horizontal shearing within the asthenosphere and the vertically-propagating SKS waves should therefore cross this upper mantle along weakly anisotropic directions and generate rather low delay times.

The mantle flow model calculated by Forte et al. (2010) is based on the joint inversion of rheological structure of the mantle and of density perturbations. Mantle viscosity profiles are issued from convection-related observables and post-glacial rebound data, whereas the density anomalies are inverted from mineral physics data, geodynamic data sets (including surface gravity anomalies, dynamic topography, divergence of plate motions and excess ellipticity of the core-mantle boundary) and seismic velocity models TX2007 and TX2008 (Simmons et al., 2007; Simmons et al., 2009), that into account permanent and temporary deployments together with direct and multi-bouncing seismic waves. Forte et al. (2010) showed that the large-scale mantle upwelling induced by the lower mantle low-velocity zone beneath South Africa should generate a radial flow in the upper mantle centered on South Africa and therefore, a northeastward flow beneath the western Indian Ocean. Their model predicts a NE trending flow beneath the Maldives and Seychelles and trending ENE beneath La Réunion. Combined to the surface plate motion, the resulting shear at asthenospheric depth should trend toward the NE in the Maldives and close to EW in La Réunion-Mauritius region, that provides also a good fit with our observed $\phi$. Beneath the Indian plate, asthenosphere is predicted to flow along NE azimuths, which is fully compatible with our observations.

The three geodynamical models discussed above strongly support a deep and active mantle circulation beneath the western part of the Indian Ocean that may induce large horizontal shear deformation at asthenospheric depth. However, while these models can explain a large part of the observed large-scale anisotropy pattern, they cannot explain the complex null and non-null anisotropy pattern observed by the seismic stations on La Réunion Island that is clearly not compatible with a single and homogeneous anisotropic layer. Such observations suggest upper mantle heterogeneities in the vicinity of La Réunion that may be 
induced by 3D local flow variations. We therefore test in the following section the influence of a plume sublithospheric spreading on the anisotropy pattern beneath La Réunion and Mauritius islands.

\subsection{Anisotropy and sublithospheric plume spreading}

The presence of a mantle plume upwelling beneath a moving plate should induce a spreading of hot material that should locally affect the asthenospheric flow pattern, particularly in the neighborhood of the plume conduit. Numerical modeling shows that the interaction of a plume with an overlying moving lithosphere should create a parabolic asthenospheric flow (PAF) pattern (e.g., Kaminski and Ribe, 2002; Ribe and Christensen, 1994; Sleep, 1990), with a symmetry axis parallel to the plate motion vector and with a spreading broadness controlled by the ratio between the plate motion velocity and the plume buoyancy flux: AVratio $=1 / P$ with $P$ the parabolic width in $\mathrm{km}$. PAF pattern is also characterized by a stagnation point, where the normal asthenospheric flow and the horizontal spreading of the upwelling material beneath the lithosphere cancel each other, representing therefore a place of expected weak mantle deformation and by a stagnation line limiting the asthenosphere originating from the plume from the normal asthenosphere (Sleep, 1990).

Although the little number of seismic stations and of splitting measurements available in the present study cannot provide a unique solution from data inversion, we calculated PAF models using the method proposed by Savage and Sheehan (2000) and Walker et al. (2001, 2005b) in order to test families of PAF models that may explain the anisotropy locally observed at La Réunion and at Mauritius stations and therefore, that may provide constraints on some possible plume characteristics (such as its location and its AVratio).

By using a hydrodynamical streaming potential function (Hammond et al., 2005; Milne-Thomson, 1968; Savage and Sheehan, 2000; Walker et al., 2001; Walker et al., 2005b), we determined the flow lines corresponding to the spreading of a vertical upwelling interacting with a horizontal flow stream. We investigated a large number of models with a lithospheric plate moving in azimuths ranging from NS to $\mathrm{N}^{\circ} 60^{\circ} \mathrm{E}$, with plume center conduits located within $600 \mathrm{~km}$ distance around La Réunion, and with AVratio between $0.001 \mathrm{~km}^{-1}$ and $0.02 \mathrm{~km}^{-1}$. We evaluated each PAF model on its ability in explaining simultaneously the $\phi$ trending close to $\mathrm{N} 080^{\circ} \mathrm{E}$ at MRIV, the $\phi$ trending $\mathrm{N} 090^{\circ} \mathrm{E}$ to $\mathrm{N} 110^{\circ} \mathrm{E}$ at RER, and the good nulls observed at RER for SW backazimuths. We calculated a misfit summing a "null misfit" that quantified the difference between each null backazimuth and the normal to the closest point on the stagnation line, and a "non-null misfit" calculated from the difference between each non-null fast direction projected at a given piercing depth and the predicted flow line. We considered the measurements projected at $400 \mathrm{~km}$ depth since it may represent the depth at which the SKS rays encounter the first anisotropy. Such a simple approach assumes that the dominant part of the anisotropy lies within the asthenosphere and that fast azimuths $\phi$ are close to the flow lines.

The large number of direct modeling allows us to provide some general quantitative insights on the plume parameters:

- AVratio: large AVratio values ranging between 0.015 and $0.030 \mathrm{~km}^{-1}$ are not likely, since they imply plate velocities unrealistically too large relative to the ascending mantle flux, generating extremely elongated parabolas and therefore, weakly deflected flow. African plate velocities are amongst the lowest on Earth, with velocities typically ranging between 1.0 and $3.0 \mathrm{~cm} \mathrm{yr}^{-1}$ in the western Indian Ocean depending on the considered APM model. Large AVratio should induce dominant fast polarization directions $\phi$ parallel to the APM, and cannot explain EW trending $\phi$, as observed at RER and ENE trending $\phi$ at MRIV. Small AVratio (i.e., lower than $0.006 \mathrm{~km}^{-1}$ ) are instead required in order to get $\phi$ trending locally at large angle to the plate motion direction. They indicate low plate motion velocities relative to the plume vertical flux and therefore, a rather broad plume spreading beneath the lithosphere. In the case of La Réunion plume, the best fits are observed with AVratio ranging between 0.002 and $0.006 \mathrm{~km}^{-1}$ and suggest a plume spreading over more than $600 \mathrm{~km}$.

- APM: our PAF models cannot constrain the APM since good fits are found for most of the range of tested APM. We however consider an APM trending $\mathrm{N} 030^{\circ} \mathrm{E}$ in the following discussions, since it corresponds to the large-scale trend of the hotspot track.

- Plume center location: a robust conclusion of our modeling is that La Réunion stations have to be located upstream from the plume center since the plume spreading does not generate downstream EW-trending flow. In other words, in order to explain our splitting measurements by a PAF pattern, the plume center cannot be south of La Réunion Island. Our best models such as the example presented in Fig. 6 suggest instead a plume center located $100-200 \mathrm{~km}$ north of La Réunion (indicated by the yellow star in Fig. 6). Such plume locations and small AVratio values imply a distance between the plume conduit and the stagnation point of about $250 \mathrm{~km}$, compatible with the value proposed by Sleep (1990). Such model suggests a stagnation point located SW of La Réunion Island that explains well the numerous and unexpected nulls for such SW backazimuths.

A closer look at the PAF patterns shows that flow oriented at large angle to the plate motion can be found in two arc-shaped areas joining the plume conduit to the stagnation point, indicated by grey areas in Fig. 6, that represent the regions in the asthenosphere where one may expect $\phi$ ranging from $\mathrm{N} 080^{\circ} \mathrm{E}$ to $\mathrm{N} 110^{\circ} \mathrm{E}$. Although the PAF pattern is symmetric relative to the APM vector, the shape and size of these regions is not symmetrical in the geographical reference frame, depending on the APM azimuth. In the case of La Réunion plume, the largest patch of EW-trending $\phi$ is located SE of the plume conduit.

Fig. 7 summarizes the results of PAF models calculated for a particular grid search characterized by: (i) a plate moving $\mathrm{N} 030^{\circ} \mathrm{E}$ (i.e., parallel to the trend of the hotspot track), (ii) plume centers located within the bounding box specified by $-24^{\circ}$ to $-17^{\circ} \mathrm{N}$ of latitude, and $52^{\circ}$ to $61^{\circ} \mathrm{E}$ of longitude, by $0.5^{\circ}$ steps and, (iii) AVratio varying from 0.001 to $0.013 \mathrm{~km}^{-1}$ by 0.002 steps. The tested plume center locations are shown in map by white and red circles in Fig. 7. A red circle indicates that the tested location belongs to the $10 \%$ best models with the smallest misfits. Such a map clearly shows that none of the $10 \%$ best models are characterized by plume center located south of La Réunion Island but instead, that the best PAF models suggest a plume center located north of La Réunion. Although a plume conduit directly beneath La Réunion Island cannot be ruled out, the density contouring of the best fitting models shown in Fig. 7a together with the frequency plot of the $10 \%$ best model locations show that the maximum number of the best-fitting models are located in the range $54-57^{\circ} \mathrm{E}$ in longitude and -21 to $-19^{\circ} \mathrm{N}$ in latitude, i.e., $100-200 \mathrm{~km}$ north of La Réunion and $100-$ $200 \mathrm{~km}$ west of Mauritius. The frequency plots of the AVratio of the $10 \%$ best models presented in Fig. 7 suggest AVratio smaller than $0.006 \mathrm{~km}^{-1}$.

Our prediction of a plume center located north of La Réunion is surprising if one considers a hotspot geometry as a punctual source of magma crossing the overlying lithosphere and generating a linear 


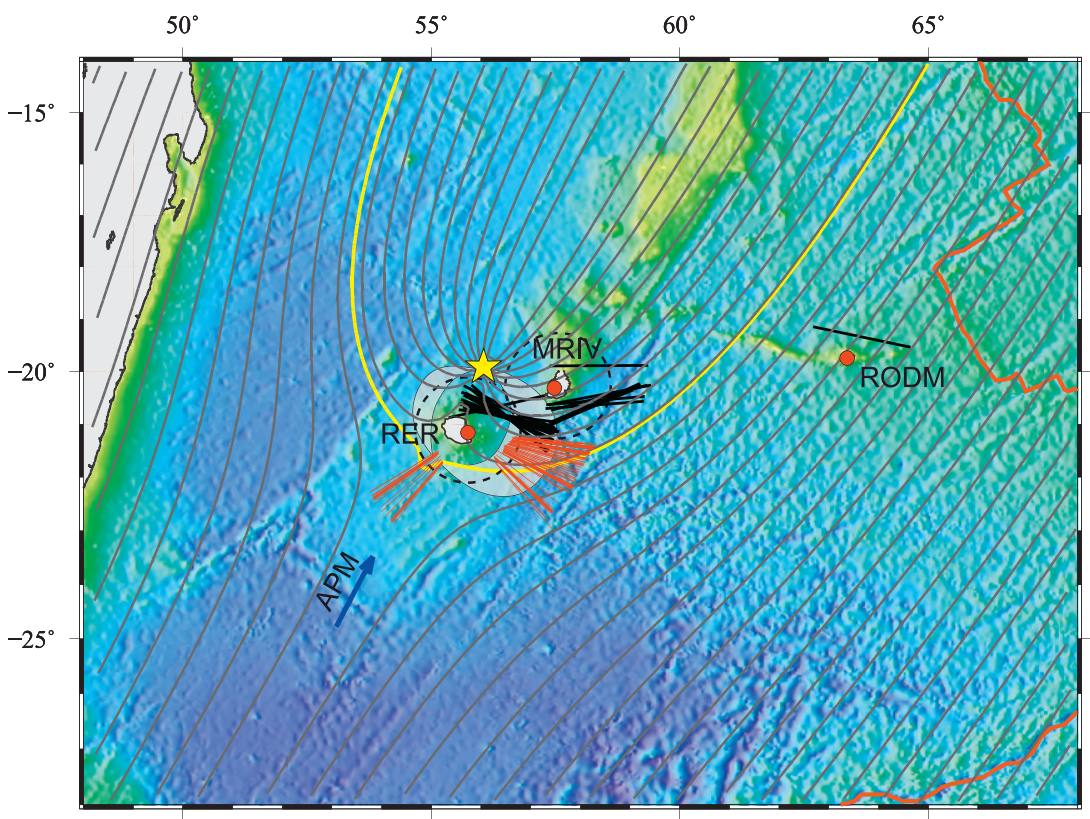

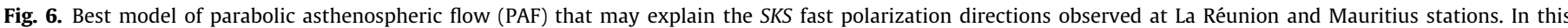

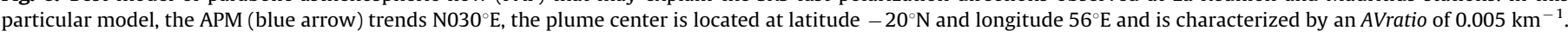

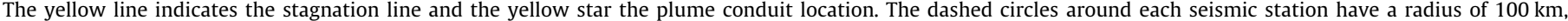

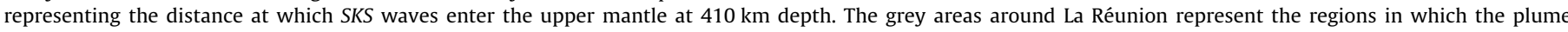

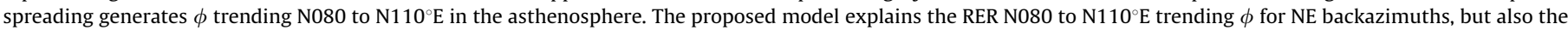

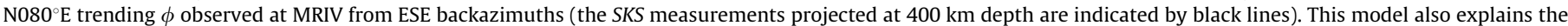

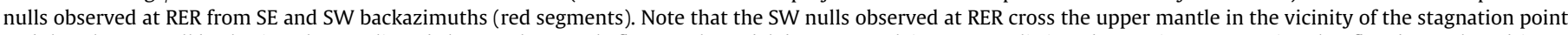

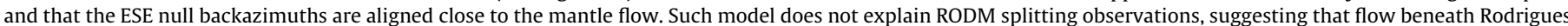

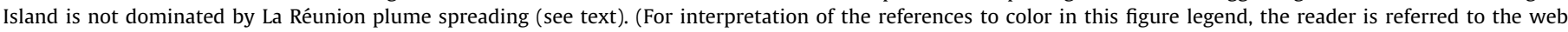
version of this article.)
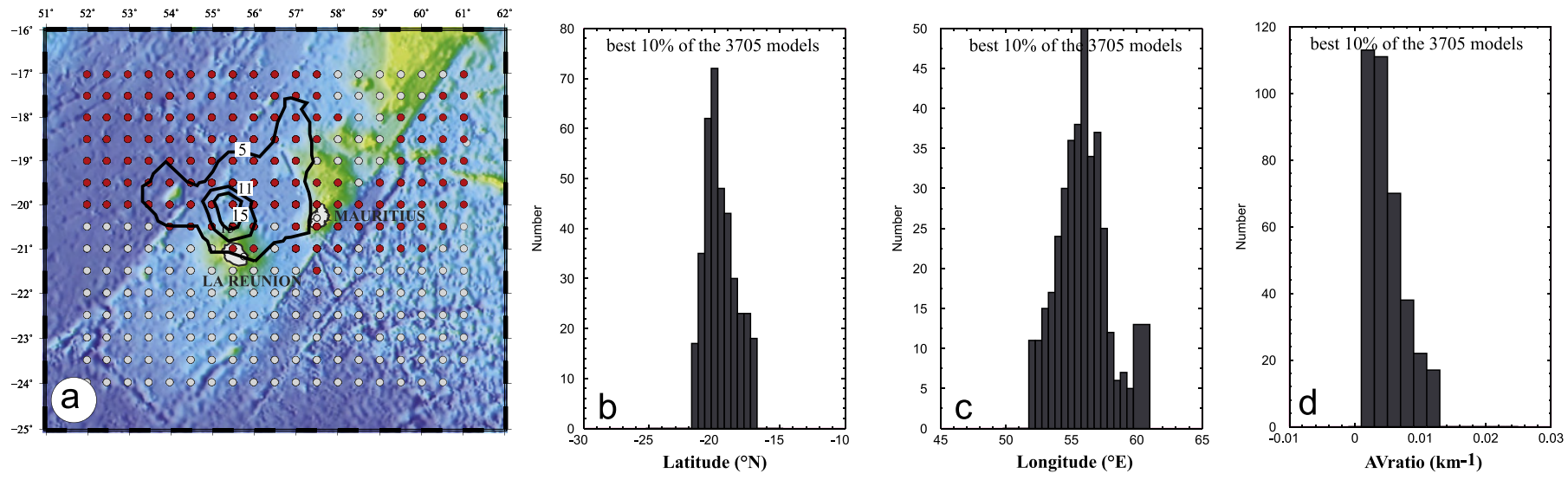

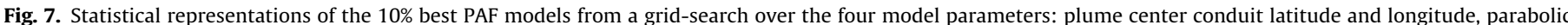

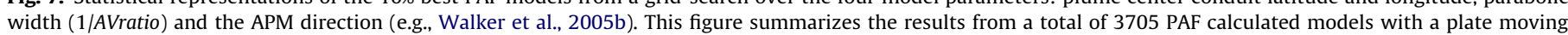

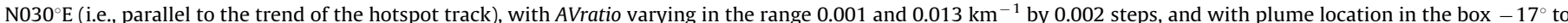

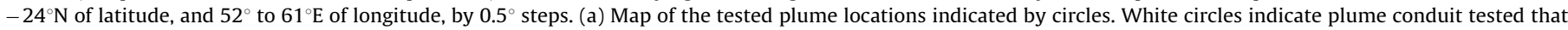

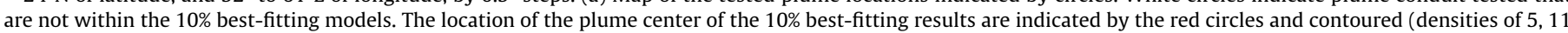

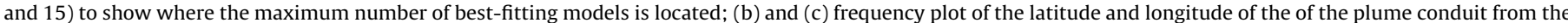

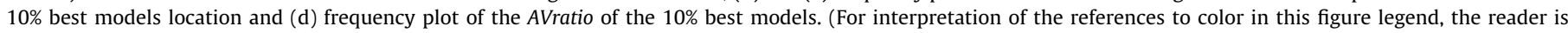
referred to the web version of this article.)

volcanic alignment. Several arguments suggest, however, that La Réunion hotspot may differ from such an archetype hotspot model: To a first approximation, the ages of the emitted lavas vary from 65 to $0 \mathrm{Ma}$ from the Deccan traps in India to La Réunion (Duncan and Hargraves, 1990), while the regional basalt ages observed in La Réunion and Mauritius islands (Duncan, 1990; McDougall, 1971; Moore et al., 2011) show variations between 0 and $3 \mathrm{Ma}$ and between 0 and $8 \mathrm{Ma}$, respectively. This indicates a rather long period of simultaneous volcanic activity on the two islands located $200 \mathrm{~km}$ apart. Assuming that the 2 islands are issued from a single mantle plume, such regional volcanic activity during the last 3-5 Ma likely requires a complex melt distribution at depth, inconsistent with a single and punctual source of partial melting and of magma concentration. Numerical modeling of plume-lithosphere interaction (Thoraval et al., 2006) demonstrates that partial melting may be present upstream and downstream simultaneously, and therefore that the present-day location of the hotspot volcanic activity at the Piton de la Fournaise is not located directly over the plume conduit in the asthenosphere and that several magma chambers may coexist at large distance from each other above a single mantle plume that 
spreads beneath a moving lithosphere. Finally, it has to be emphasized that the present-day volcano position may be strongly influenced or even controlled by lithospheric pre-existing structures and may therefore appear at some offset from the plume center. It has been shown for instance that the present-day location of La Réunion hotspot is likely controlled by preexisting lithospheric structures (Deplus et al., 2007), such as a fossil triple junction as suggested by magnetic anomalies (Bissessur et al., 2009; Bissessur, 2011) and that the $\mathrm{N} 120^{\circ}$ E-trending alignment of the Piton de la Fournaise and the extinct Piton des Neiges volcanoes is parallel to inherited crustal structures (Michon et al., 2007) that may have controlled the successive emplacements of La Réunion volcanic edifices.

\subsection{Anisotropy beneath the Rodrigues Ridge}

If some families of PAF models may explain anisotropy trends observed at RER and MRIV, none may simultaneously explain the anisotropy at RODM on Rodrigues Island. Large-scale plume spreading beneath La Réunion should indeed induce $\phi$ trending NNE to NE at RODM (Fig. 5), which is clearly not observed, suggesting another dominant source of anisotropy beneath this island. Rodrigues Island lies at the eastern end of the $400 \mathrm{~km}$-long Rodrigues Ridge. While Behn et al.'s (2004), Conrad and Behn's (2010) and Becker and Faccenna's (2011) models involving a flow driven by the deep mantle circulation predict E-W trending $\phi$ in this region, several arguments favor an alternative hypothesis of a maintained plumeridge interaction through an asthenospheric channeled flow preserving a connection between La Réunion plume and the Central Indian Ridge (Duncan and Hargraves, 1990; Dyment et al., 2007; Morgan, 1978). These arguments may be summarized by (i) the presence of recent (1.5 Ma) volcanic activity on this island (e.g., McDougall et al., 1965), (ii) the shape and the smooth morphology of the Central Indian Ridge segment at latitude ranging $17^{\circ} \mathrm{S}-21^{\circ} \mathrm{S}$ and (iii) the geochemical signatures of rocks dredged along this ridge segment (e.g., Dyment et al., 2001; Furi et al., 2011; Hémond et al., 2009). In such plume-ridge interaction model, the parallelism between the Rodrigues ridge (trending $\mathrm{N} 100^{\circ} \mathrm{E}$ ) and our new observed $\phi$ (trending $\mathrm{N} 102^{\circ} \mathrm{E}$ ) may represent another evidence of an asthenospheric flow between the hotspot track and the Central Indian ridge. From SKS splitting measurements, Fontaine et al. (2005) suggested a similar plume-ridge interaction at Española (in the Galápagos archipelago) in order to explain an anomalous fast polarization direction trending close to the current direction of migration of the Galápagos Spreading Center (Harpp and Geist, 2002). Denser seismic observations between the hotspot track and the Central Indian ridge are obviously required to discuss the nature of the Rodrigues ridge and to quantify the possible plume-ridge interactions.

\section{Conclusions}

By analyzing seismic anisotropy beneath islands located on or near La Réunion hotspot track, we evidenced several signatures that are likely dominated by different processes. Stations on the oldest section of La Réunion hotspot track on the Indian plate show a NE-trending anisotropy, likely dominated by an asthenospheric deformation induced by relative motion between the plate and the deep mantle flow. A similar signature is observed at the Seychelles station on the African plate. Anisotropy in La Réunion-Mauritius region is dominated by EW-trending $\phi$. The flow predicted by several geodynamic models based on tomography-derived densities and other geophysical observables are compatible with a plate dragged by deep mantle convection, induced by the buoyancy-driven South African superswell upwelling. However, while large-scale mantle flow can explain the large-scale anisotropy pattern observed in the SW Indian Ocean, these models fail to explain the complex pattern of anisotropy beneath La Réunion, which is not compatible with a single anisotropic layer. Thus, we favor the local influence of small-scale upper mantle heterogeneities induced by a mantle plume interacting with the bottom of the lithosphere. From simple and non-unique numerical models of plume spreading beneath the lithosphere, we show that the EW to $\mathrm{N} 100^{\circ} \mathrm{E}$ trending $\phi$ and the nulls observed on $\mathrm{La}$ Réunion but also the $\mathrm{N} 080^{\circ} \mathrm{E}$ trending $\phi$ on Mauritius Island can be rather well explained by a plume spreading with a feeding conduit located $100-200 \mathrm{~km}$ north of La Réunion Island at asthenospheric depth. This result suggests that La Réunion could lie close to the southern tip of the upstream Réunion plume spreading. Such model is not able to explain the anisotropy in Rodrigues Island implying that anisotropy in this region is instead explained by either the deep mantle circulation or, as already proposed few decades ago by Morgan (1978), by a channeled asthenospheric flow going from the plume track toward the Central Indian Ridge. Since the number of sites analyzed is small in regard of the size of the ocean basin, further investigations and more sophisticated modeling combining simultaneous large-scale mantle convection and short-scale plume upwelling are obviously needed to test the proposed hypotheses, and to improve our knowledge on this potential plume structure, on its origin and on its interaction with the slowly-moving oceanic lithosphere. Imaging the mantle beneath La Réunion hotspot, from the crust to the core and characterizing the possible interaction of the plume with the lithosphere and the neighboring ridges are the challenging aims of the RHUM-RUM (Réunion hotspot and Upper Mantle-Réunion's Unterer Mantle) French-German project scheduled for the period 2012-2015.

\section{Acknowledgments}

This work was supported by the French Agence Nationale de la Recherche, project RHUM-RUM ANR-11-BS56-0013. Thanks to IRIS, GEOFON and GEOSCOPE global networks for the availability of high quality data. Thanks also to the Institut de Physique du Globe de Paris for providing data recorded by the Observatoire Volcanologique du Piton de la Fournaise (IPGP/OVPF) and also to the UnderVolc project ANR_08_RISK_011 (P.I.F. Brenguier), for which seismometers were provided by the French mobile seismic network SisMob from the Centre National de la Recherche Scientifique-Institut National des Sciences de l'Univers (CNRSINSU). We are thankful to M.D. Behn and an anonymous reviewer for the constructive comments and suggestions, to C.P. Conrad for providing his gridded mantle flow models, to T.W. Becker for providing SKS splitting predicted from his published geodynamic model and to A. Forte for discussions around geodynamic flow models. The paper also benefited of fruitful discussions with L. Michon. We thank K. Walker for the parabolic flow analysis. SplitLab software used for the splitting measurements and the SKS splitting database used in Fig. 1 are available at http://www. gm.univ-montp2.fr/splitting/. Information about the RHUM-RUM project may be found at http://www.rhum-rum.net.

\section{Appendix A. Supplementary materials}

Supplementary data associated with this article can be found in the online version at http://dx.doi.org/10.1016/j.epsl.2012.11.017.

\section{References}

Androvandi, S., Davaille, A., Limare, A., Foucquier, A., Marais, C., 2011. At least three scales of convection in a mantle with strongly temperature-dependent viscosity. Phys. Earth Planet. Inter. 188 (3-4), 132-141, http://dx.doi.org/ 10.1016/j.pepi.2011.07.004. 
Barruol, G., Silver, P.G., Vauchez, A., 1997. Seismic anisotropy in the eastern US: deep structure of a complex continental plate. J. Geophys. Res. 102, 8329-8348.

Barruol, G., Hoffmann, R., 1999. Seismic anisotropy beneath the Geoscope stations from SKS splitting. J. Geophys. Res. 104, 10757-10774.

Barruol, G., Ben Ismail, W., 2001. Upper mantle anisotropy beneath the African IRIS and Geoscope stations. Geophys. J. Int. 146 (2), 549-561, http://dx.doi.org/ 10.1046/j.0956-540x.2001.01481.x.

Barruol, G., Reymond, D., Fontaine, F.R., Hyvernaud, O., Maurer, V., Maamaatuaiahutapu, K., 2006. Characterizing swells in the southern Pacific from seismic and infrasonic noise analyses. Geophys. J. Int. 164 (3), 516-542, http://dx.doi.org/ 10.1111/J.1365-246X.2006.02871.X.

Barruol, G., Suetsugu, D., Shiobara, H., Sugioka, H., Tanaka, S., Bokelmann, G.H.R. Fontaine, F.R., Reymond, D., 2009. Mapping upper mantle flow beneath French Polynesia from broadband ocean bottom seismic observations. Geophys. Res. Lett. 36, L14301, http://dx.doi.org/10.1029/2009GL038139.

Barruol, G., Bonnin, M., Pedersen, H., Bokelmann, G.H.R., Tiberi, C., 2011. Belt-parallel mantle flow beneath a halted continental collision: the Western Alps. Earth Planet. Sci. Lett. 302, 429-438, http://dx.doi.org/10.1016/j.epsl.2010.12.040.

Bascou, J., Delpech, G., Vauchez, A., Moine, B.N., Cottin, J.Y., Barruol, G., 2008. An integrated study of microstructural, geochemical and seismic properties data of the lithospheric mantle above the Kerguelen plume (Indian Ocean). Geochem. Geophys. Geosyst. 9, Q04036, http://dx.doi.org/10.1029/2007GC001879.

Becker, T.W., Boschi, L., 2002. A comparison of tomographic and geodynamics models. Geochem. Geophys. Geosyst. 3 (1), http://dx.doi.org/10.1029/2001GC000171.

Becker, T.W., Chevrot, S., Schulte-Pelkum, V., Blackman, D.K., 2006. Statistical properties of seismic anisotropy predicted by upper mantle geodynamic models. J. Geophys. Res. 111 (B8), B08309, http://dx.doi.org/10.1029/2005jb004095.

Becker, T.W., Faccenna, C., 2011. Mantle conveyor beneath the Tethyan collisional belt. Earth Planet. Sci. Lett. 310, 453-461, http://dx.doi.org/10.1016/ j.epsl.2011.08.21.

Becker, T.W., Lebedev, S., Long, M.D., 2012. On the relationship between azimuthal anisotropy from shear waves splitting and tomographic models. J. Geophys. Res. 117, B01306, http://dx.doi.org/10.1029/2011JB008705.

Behn, M.D., Conrad, C.P., Silver, P.G., 2004. Detection of upper mantle flow associated with the African superplume. Earth Planet. Sci. Lett. 224, 259-274, http://dx.doi.org/ 10.1016/j.epsl.2004.05.026.

Ben Ismail, W., Mainprice, D., 1998. An olivine fabric database: an overview of upper mantle fabrics and seismic anisotropy. Tectonophysics 296, 145-157.

Bissessur, D., Dyment, J., Deplus, C., Yatheesh, V., 2009. A triple junction trace beneath Reunion island? Insight from marine magnetic anomalies, EGU 2009. Geophysical Research Abstracts, Vienna, p. 6383.

Bissessur, D., 2011. Structure et mise en place du bassin des Mascareignes dans le cadre géodynamique de l'Océan Indien. Caractérisation des relations point chaud - lithosphère océanique en contextes intraplaque et d'interaction avec une dorsale. Doctorat Thesis, IPG Paris, 168 pp.

Brenguier, F., Kowalski, P., Staudacher, T., Ferrazzini, V., Lauret, F., Boissier, P., Catherine, P., Lemarchand, A., Pequegnat, C., Meric, O., Pardo, C., Peltier, A., Tait, S., Shapiro, N.M., Campillo, M., Di Muro, A., 2012. First Results from the UnderVolc High Resolution Seismic and GPS Network deployed on Piton de la Fournaise volcano. Seismol. Res. Lett. 83 (1), 97-102, http://dx.doi.org/ 10.1785/gssrl.83.1.97.

Conrad, C.P., Lithgow-Bertelloni, C., 2006. Influence of continental roots and asthenosphere on plate-mantle coupling. Geophys. Res. Lett. 33, L05312, http://dx.doi.org/10.1029/2005GL025621.

Conrad, C.P., Behn, M.D., Silver, P.G., 2007. Global mantle flow and the development of seismic anisotropy: differences between the oceanic and continental upper mantle. J. Geophys. Res. 112 (B7), B07317, http://dx.doi.org/10.1029/ 2006 jb004608.

Conrad, C.P., Behn, M.D., 2010. Constraints on lithosphere net rotation and asthenospheric viscosity from global mantle flow models and seismic anisotropy. Geochem. Geophys. Geosyst. 11, Q05w05, http://dx.doi.org/10.1029/ 2009 gc002970.

Debayle, E., Kennett, B.L.N., Priestley, K., 2005. Global azimuthal seismic anisotropy and the unique plate-motion deformation of Australia. Nature 433, 509-512, http://dx.doi.org/10.1038/nature03247.

Deplus, C., de Voogd, B., Dyment, J., Depuiset, F., Sisavath, E., 2007. Does the Reunion Hotspot Volcano Emplace on a Fossil Ridge or a Fracture Zone? AGU 2007 Fall Meeting. Eos Transactions AGU, San Francisco, pp. V31F-05.

Duncan, R.A., 1990. The volcanic record of the Réunion hotspot. In: Proceedings of Ocean Drilling Program, Scientific Results, pp. 3-10.

Duncan, R.A., Hargraves, R.B., 1990. 40Ar/39Ar Geochronology of basement rocks from the Mascarene plateau, the Chagos bank and the Maldives ridge. In: Proceedings of Ocean Drilling Program, Scientific Results, pp. 43-51.

Dyment, J., Hémond, C., Guillou, H., Maia, M., Briais, A., Gente, P., 2001. Central Indian ridge and Réunion hot spot in Rodrigues area: another type of ridge-hot spot interaction? Eos Trans. AGU 82 (47), Fall Meet. Suppl., Abstract T31D-05.

Dyment, J., Lin, J., Baker, E.T., 2007. Ridge-hotspot interactions: what mid-ocean ridges tell us about deep earth processes. Oceanography 20 (1), 102-115.

Fontaine, F.R., Hooft, E.E.E., Burkett, P.G., Toomey, D.R., Solomon, S.C., Silver, P.G., 2005. Shear wave splitting beneath Galápagos archipelago. Geophys. Res. Lett. 32, http://dx.doi.org/10.1029/2005GL024014.

Fontaine, F.R., Barruol, G., Tommasi, A., Bokelmann, G.H.R., 2007. Upper mantle flow beneath French Polynesia from shear-wave splitting. Geophys. J. Int. 170 (3), 1262-1288, http://dx.doi.org/10.1111/j.1365-246X.2007.03475.x.
Fontaine, F.R., Barruol, G., Kenneth, B.L.N., Bokelmann, G.H.R., Reymond, D., 2009 Upper mantle anisotropy beneath Australia and Tahiti from $P$-wave polarizationimplication for real-time earthquake location. J. Geophys. Res. 114, B03306, http://dx.doi.org/10.1029/2008JB005709.

Forte, A., Quéré, S., Moucha, R., Simmons, N.A., Grand, S.P., Mitrovica, J.X., Rowley, D.B., 2010. Joint seismic-geodynamic-mineral physical modelling of African geodynamics: a reconciliation of deep-mantle convection with surface geophysical constraints. Earth Planet. Sci. Lett. 295, 329-341, http://dx.doi.org/ 10.1016/j.epsl.2010.03.017.

Fowler, C.M.R., 1990. The Solid Earth. An Introduction to Global Geophysics. Cambridge University Press, Cambridge, 472 pp.

Furi, E., Hilton, D.R., Murton, B.J., Hemond, C., Dyment, J., Day, J.M.D., 2011. Helium isotope variations between Reunion Island and the Central Indian Ridge (17 degrees-21 degrees S): new evidence for ridge-hot spot interaction. J. Geophys. Res. 116, B02207 (17pp.), http://dx.doi.org/10.1029/2010jb007609.

Gripp, A.E., Gordon, R.G., 1990. Current plate velocities relative to the hotspots incorporating the Nuvel-1 global plate motion model. Geophys. Res. Lett. 17, 1109-1112.

Gripp, A.E., Gordon, R.B., 2002. Young tracks of hotspots and current plate velocities. Geophys. J. Int. 150, 321-361.

Hammond, J.O.S., Kendall, J.M., Rümpker, G., Wookey, J., Teanby, N., Joseph, P., Ryberg, T., Stuart, G., 2005. Upper mantle anisotropy beneath the Seychelles microcontinent. J. Geophys. Res. 110, B1140, http://dx.doi.org/10.1029/ 2005JB003757.

Harpp, K.S., Geist, D., 2002. Wolf-Darwin lineament and plume-ridge interaction in northern Galápagos. Geochem. Geophys. Geosyst. 3 (11), 8504, http://dx.do i.org/10.1029/2002GC000370.

Hémond, C., Janin, M., Maia, M., Furi, E., Hilton, D., Murton, B., Dyment, J., 2009. Indian ridges, hotspots, interaction: Réunion central Indian ridge and Amstersdam St Pau Southeast Indian ridge cases. Geochim. Cosmochim. Acta 73 (13) A521-A521.

Hess, H.H., 1964. Seismic anisotropy of the uppermost mantle under oceans. Nature 203, 629-631

Kaminski, E., Ribe, N.M., 2002. Timescale for the evolution of seismic anisotropy in mantle flow. Geochem. Geophys. Geosyst. 3 (1), 1051 (17pp.), http://dx.doi. org/10.1029/2001GC000222.

Kreemer, C., 2009. Absolute plate motions constrained by shear wave splitting orientations with implications for hot spot motions and mantle flow. J. Geophys. Res. 114, B10405, http://dx.doi.org/10.1029/2009jb006416.

Li, X., Kind, R., Yuan, X., Wölbern, I., Hanka, W., 2004. Rejuvenation of the lithosphere by the Hawaiian plume. Nature 427, 827-829.

Mainprice, D., Silver, P.G., 1993. Interpretation of SKS-waves using samples from the subcontinental lithosphere. Phys. Earth Planet. Inter. 78, 257-280.

Mainprice, D., Barruol, G., Ben Ismail, W., 2000. The seismic anisotropy of the Earth's mantle: from single crystal to polycrystal. In: Karato, S.I., Forte, A. Liebermann, R.C., Masters, G., Stixrude, L. (Eds.), Earth's Deep Interior: Minera Physics and Tomography from the Atomic to the Global Scale. Geophysical Monograph. AGU, Washington, DC, pp. 237-264.

McDougall, I., Upton, B.G.J., Wadsworth, W.J., 1965. A geological reconnaissance of Rodriguez Island Indian Ocean. Nature 206, 26-27, http://dx.doi.org/10.1038/ $206026 a 0$.

McDougall, I., 1971. Geochronology and evolution of young volcanic islands of Réunion, Indian Ocean. Geochim. Cosmochim. Acta 35 (3), 261-270, http://dx. doi.org/10.1016/0016-7037(71)90037-8.

Michon, L., Saint-Ange, F., Bachelery, P., Villeneuve, N., Staudacher, T., 2007. Role of the structural inheritance of the oceanic lithosphere in the magmato-tectonic evolution of Piton de la Fournaise volcano (La Reunion Island). J. Geophys. Res. 112, B04205, http://dx.doi.org/10.1029/2006jb004598.

Milne-Thomson, L.M., 1968. Theoretical Hydrodynamics. Macmillan, New York.

Montagner, J.P., 2002. Upper mantle low anisotropy channels below the Pacific plate. Earth Planet. Sci. Lett. 202, 263-274, http://dx.doi.org/10.1016/S0012 821X(02)00791-4.

Moore, J., White, W.M., Paul, D., Duncan, R.A., Abouchami, W., Galer, S.J.G., 2011 Evolution of shield-building and rejuvenescent volcanism of Mauritius J. Volcanol. Geotherm. Res. 207 (1-2), 47-66, http://dx.doi.org/10.1016/j.jvolgeores. 2011.07.005.

Morgan, W.J., 1978. Rodriguez, Darwin, Amsterdam,..., a second type of hotspot island. J. Geophys. Res. 83 (B11), 5357-5360.

Müller, R.D., Royer, J.Y., Lawyer, L.A., 1993. Revised plate motions relatives to the hotspots from combined Atlantic and Indian hotspot tracks. Geology 21, 275-278

Nicolas, A., Christensen, N.I., 1987. Formation of anisotropy in upper mantle peridotites - A review. In: Fuchs, K., Froidevaux, C. (Eds.), Composition, Structure and Dynamics of the Lithosphere-Asthenosphere System. Geodyn. Ser.. AGU, Washington, DC, pp. 111-123.

Quéré, S., Rowley, D.B., Forte, A.M., Moucha, R., 2007. No-Net-Rotation and IndoAtlantic hotspot reference frames: towards a new view of tectonic plate motions and Earth dynamics, pp. EOS Transactions AGU, 88 (52), AGU Fall Meet. Suppl., Abstract U34A-03.

Restivo, A., Helffrich, G., 1999. Teleseismic shear wave splitting measurements in noisy environments. Geophys. J. Int. 137, 821-830.

Ribe, N.M., Christensen, U.R., 1994. Three-dimensional modeling of plumelithosphere interaction. J. Geophys. Res. 99, 669-682.

Ritsema, J., van Heijst, H., Woodhouse, J., 1999. Complex shear wave velocity structure imaged beneath Africa and Iceland. Science 286, 1925-1928.

Ritsema, J., van Heijst, H., Woodhouse, J.H., 2004. Global transition zone tomography. J. Geophys. Res. 109, B02302, http://dx.doi.org/10.1029/2003JB002610. 
Russo, R., Okal, E., 1998. Shear wave splitting and upper mantle deformation in French Polynesia: evidence for small-scale heterogeneity related to the society hotspot. J. Geophys. Res. 103, 15089-15107.

Savage, M.K., 1999. Seismic anisotropy and mantle deformation: what have we learned from shear wave splitting? Rev. Geophys. 37, 65-106.

Savage, M.K., Sheehan, A.F., 2000. Seismicanisotropyand mantle flow from the Great Basin to the Great Plains, western United States. J. Geophys. Res. 105 (B6), 13715-13734.

Schulte-Pelkum, V., Masters, G., Shearer, P.M., 2001. Upper mantle anisotropy from long-period P polarization. J. Geophys. Res. 106, 21917-21934.

Silver, P.G., Chan, W.W., 1991. Shear wave splitting and subcontinental mantle deformation. J. Geophys. Res. 96, 16429-16454.

Silver, P.G., Savage, M.K., 1994. The interpretation of shear-wave splitting parameters in the presence of two anisotropic layers. Geophys. J. Int. 119, 949-963.

Silver, P.G., 1996. Seismic anisotropy beneath the continents: probing the depths of geology. Annu. Rev. Earth Planet. Sci. 24, 385-432.

Simmons, N.A., Forte, A.M., Grand, S.P., 2007. Thermochemical structure and dynamics of the African superplume. Geophys. Res. Lett. 34 (2), L022301 (5pp.), http://dx.doi.org/10.1029/2006GL028009.

Simmons, N.A., Forte, A., Grand, S.P., 2009. Joint seismic, geodynamic and mineral physical constraints on three-dimensional mantle heterogeneity: implications for the relative importance of thermal versus compositional heterogeneity. Geophys. J. Int. 17 (3), 1284-13004.

Sleep, N.H., 1990. Hotspots and mantle plumes: some phenomenology. J. Geophys. Res. 95, 6715-6736.

Suetsugu, D., Shiobara, H., Sugioka, H., Barruol, G., Schindelé, F., Reymond, D. Bonneville, A., Debayle, E., Isse, T., Kanazawa, T., Fukao, Y., 2005. Probing South Pacific mantle plumes with Broadband OBS. Eos 86 (44), 429-435, http://dx.doi.org/ $10.1029 / 2005$ EO440001
Suetsugu, D., Isse, T., Tanaka, S., Obayashi, M., Shiobara, H., Sugioka, H., Kanazawa, T., Fukao, Y., Barruol, G., Reymond, D., 2009. South Pacific mantle plumes imaged by seismic observation on islands and seafloor. Geochem. Geophys. Geosyst. 10, Q11014, http://dx.doi.org/10.1029/2009GC002533.

Thoraval, C., Tommasi, A., Doin, M.P., 2006. Plume-lithosphere interaction beneath a fast moving plate. Geophys. Res. Lett. 33 (L01301), http://dx.doi.org/10.1029/ 2005GL024047.

Tommasi, A., Vauchez, A., Russo, R., 1996. Seismic anisotropy in oceanic basins: resistive drag of the sublithospheric mantle? Geophys. Res. Lett. 23, 2991-2994.

Walker, K.T., Bokelmann, G.H.R., Klemperer, S.L., 2001. Shear-wave splitting to test mantle deformation models around Hawaii. Geophys. Res. Lett. 28, 4319-4322.

Walker, K.T., Bokelmann, G.H.R., Klemperer, S.L., Bock, G., 2005a. Shear-wave splitting around the Eifel hotspot: evidence for a mantle upwelling. Geophys. J. Int. 163 (3), 962-980, http://dx.doi.org/10.1111/j.1365-246X.2005.02636.x.

Walker, K.T., Bokelmann, G.H.R., Klemperer, S.L., Nyblade, A.A., 2005b. Shear-wave splitting around hotspots: evidence for upwelling-related mantle flow? In: Foulger, G.R., Natland, J.H., Presnall, D.C., Anderson, D.L. (Eds.), Plates, Plumes And Paradigms. Geological Society of America, pp. 171-192.

Wolfe, C., Silver, P.G., 1998. Seismic anisotropy of oceanic upper mantle: shear wave splitting methodologies and observations. J. Geophys. Res. 103, 749-771.

Wuestefeld, A, Bokelmann, G.H.R., Zaroli, C., Barruol, G., 2008. SplitLab: a shear-wave splitting environment in Matlab. Comput. Geosci. 34, 515-528, http://dx.doi.org/ 10.1016/j.cageo.2007.08.002.

Wuestefeld, A., Bokelmann, G.H.R., Barruol, G., Montagner, J.P., 2009. Identifying global seismic anisotropy patterns by correlating shear-wave splitting and surface-wave data. Phys. Earth Planet. Inter. 176, 198-212, http://dx.doi.org/ 10.1016/j.pepi.2009.05.006 